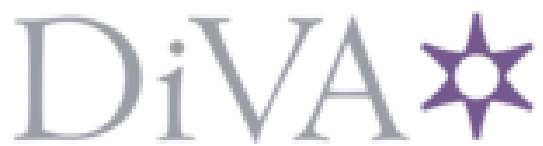

http://www.diva-portal.org

This is the published version of a paper published in .

Citation for the original published paper (version of record):

Hartwig, F. (2012)

The Use of Capital Budgeting and Cost of Capital Estimation Methods in Swedish Listed Companies

Journal of Applied Business Research, 28(6): 1451-1476

Access to the published version may require subscription.

N.B. When citing this work, cite the original published paper.

Permanent link to this version:

http://urn.kb.se/resolve?urn=urn:nbn:se:hig:diva-12820 


\title{
The Use Of Capital Budgeting And Cost Of Capital Estimation Methods In Swedish-Listed Companies
}

Fredrik Hartwig, Uppsala University, Sweden

\begin{abstract}
In this paper Swedish listed companies' use of capital budgeting and cost of capital estimation methods in 2005 and 2008 are examined. The relation between company characteristics and choice of methods is investigated and both within-country longitudinal and cross-country comparisons are made. Larger companies seem to have used capital budgeting methods more frequently than smaller companies. When compared to U.S. and continental European companies, Swedish listed companies employed capital budgeting methods less frequently. In 2005 the most common method for establishing the cost of equity was by asking the investors what return they required. By 2008 CAPM was instead the most utilised method, which could indicate greater sophistication. The use of project risk when evaluating investments also seems to have gained in popularity, while the use of company risk declined. Overall, the use of sophisticated capital budgeting and cost of capital estimation methods seem to be rising and the use of less sophisticated methods declining.
\end{abstract}

Keywords: Capital Budgeting Method; Cost of Equity; Project Risk; Swedish-listed Companies

\section{INTRODUCTION}

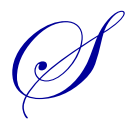

ophisticated capital budgeting methods are often "highly recommended" by financial management textbooks, e.g. net present value (NPV), whereas others that are simpler are not, e.g. undiscounted payback (e.g. Brealey and Myers, 2003; Lumby and Jones, 2003; Ross et al., 2005; Smart et al., 2007). Theoretical advice is also given on how to estimate the cost of capital. Estimation models like the capital asset pricing model (CAPM) are frequently referred to and instructions how to calculate project discounts rates, contingent on the underlying risk of the project, instead of using a single company discount rate, are presented (e.g. Brealey and Myers, 2003; Lumby and Jones, 2003; Ross et al., 2005; Smart et al., 2007). Furthermore, multinationals are advised to consider risk factors such as political and foreign exchange risk (Shapiro, 2002; Eiteman et al., 2006).

Still, the practical use of economic models can, as earlier research has shown (Graham and Harvey, 2001; Sandahl and Sjögren, 2003; Brounen et al., 2004; Danielson and Scott, 2006), deviate from what is prescribed by normative theory. Management, possibly with other goals than the principal (Jensen and Meckling, 1976), decides whether the recommended methods should be employed or not. The goal incongruence together with the information asymmetry between management and the shareholders, might lead to different practical behaviour than what is recommended by textbooks (Narayanan, 1985). And moreover, also in an ideal world where the principalagent problem does not exist or is limited, there might be a discrepancy between theory and practice. Methods that from a theoretical perspective at first sight have flaws can in practice namely be efficient and lead to shareholder wealth maximisation. Boyle and Guthrie $(1997,2006)$ showed, for example, that the employment of the payback method could be rational since the payback time approximates the option value of waiting to invest ${ }^{1}$. Moreover,

\footnotetext{
${ }^{1}$ The option value of waiting to invest is lower if the payback is faster because the cost of not investing is higher and the benefit lower, when the payback period is short. An investment should only be made if its NPV is 1)not negative and 2)not lower than the option value of not making the investment. The lower the option value (i.e. the quicker the payback), the more probable it is, all else equal, that the
} 
Holmén and Pramborg (2009) suggest that, in the presence of capital market imperfections, more sophisticated capital budgeting methods are costly to apply and therefore top managers are inclined to employ rules of thumb like the payback method. Another possible reason for why simpler methods are used could simply be that management is unsophisticated.

Thus, also without assuming the principal-agent conflict, the practical utilisation might very well be far from what is written in textbooks and taught at business schools. To illustrate this possible discrepancy between theory and practice the practical use of 1)capital budgeting methods and 2)cost of capital estimation methods in Swedish listed companies was examined. What these methods have in common is that they, if applied properly, can improve efficiency and thus be an important tool in striving for maximisation of shareholder wealth.

In the present study data was collected in year 2005 and 2008 through surveying CFO's of all listed companies with a primary quote on the Stockholm Stock Exchange. In total 193 responses from 152 companies were used in the statistical analyses, for a total response rate of $39,1 \%$. Responses were analysed in relation to eleven company characteristics with changes over time noted. The study is unique since a broad overview which focuses on the relation between the use of capital budgeting methods/cost of capital estimation methods and as many as eleven independent variables in Swedish listed companies, has never been done before.

Prior studies within corporate finance, accounting and corporate governance (e.g. Bloom and Naciri, 1989; MacArthur, 1999; Bancel and Mittoo, 2004; Albert-Roulhac and Breen, 2005; Johansson and Østergren, 2010) and other social sciences (e.g. Hofstede 1983, 1984) have identified, most probably due to differences in culture and institutions, behavioural differences between Sweden/Scandinavia and other parts of the world. In order to see differences/resemblances regarding the use of capital budgeting and cost of capital estimation methods between Sweden and U.S./continental Europe, the results here are compared to a U.S. study (Graham and Harvey, 2001) and a continental European one (Brounen et al., 2004).

Changes over time in Swedish listed companies are studied through comparing survey data from 2005 and 2008. Moreover, the results are compared to earlier Swedish studies, ranging from the 1960s to the new millennium (Renck, 1966; Tell, 1978; Yard, 1987, Andersson 1994; Segelod, 1995; Sandahl and Sjögren, 2003; Holmén and Pramborg, 2009). Thus, except for exploring the association between company characteristics and choice of methods in Swedish listed companies, this study also examines changes over time (in Swedish listed companies) and differences in space (between Swedish and U.S./continental European listed companies).

No particular independent variable is found to have driven a majority of the results. In 2005 size and industry seem to have been most important, but in 2008 there were fewer associations between those two independent variables and the practical employment of methods. The results suggest that, between the 1960s and 2008, use of NPV increased while payback and the internal rate of return declined. Moreover, between 2005 and 2008 the use of a single company wide discount rate for foreign investments declined. Swedish listed companies used CAPM less often than did U.S. companies. The overall use of methods was less extensive in Sweden than in the U.S. and continental Europe.

\section{METHODOLOGY}

\subsection{Design}

In this study the use of capital budgeting and cost of capital estimation methods by Swedish listed companies in 2005 and 2008, were examined based on a survey sent to their CFOs. All Swedish listed companies with a primary quote on the Stockholm Stock Exchange were surveyed. In some companies, none of the senior executives had the title "CFO". In those cases the survey was addressed to other corresponding senior executives

NPV will exceed the option value and consequently the more likely it is that the investment will be made. Boyle and Guthrie (1997) discuss this at greater length. 
(controllers, treasurers or $\mathrm{CEOs}^{2}$ ) who were responsible of the financial management activities.

A draft version of the survey was tested on graduate students and professors in the Department of Business Administration at Uppsala University and the Department of Business Administration and Economics at Gävle University. After some changes had been made to the preliminary version, the survey questions were tested on Sandvik's CFO.

In the survey, it was specified that the questions referred to all non-routine capital investments accepted or rejected at group/parent-company level. The reason for this framing is that the respondents otherwise, i.e. if the questions would regard all investments in the company (also in the subsidiaries), might not be able to give credible answers.

The survey, which is a replica of the survey originally used by Graham and Harvey $(2001)^{3}$, consists of three main questions ${ }^{4}$ and in total 27 sub questions:

- How often do you use the following capital budgeting methods?

- How frequently do you use the following discount rates when evaluating new projects in a foreign country?

- How do you estimate the cost of equity capital?

The range in the answering alternatives is between 0-4. If a specific capital budgeting or cost of capital estimation method was never used it should be given a 0 (zero). If the method was always used it should be given a 4. Thus, the higher the mean value, the more extensive was the reported use. Additionally, six questions regarding the independent variables were also asked in the survey (see Table 1).

Even though the survey instrument has its drawbacks (it only scratches the surface), it also has a strong merit; it enables a broad and rich overview. A broad and rich overview of the practical use of capital budgeting and cost of capital estimation methods in Swedish listed companies has never been made in Sweden before. The study is therefore, thanks to the survey instrument, unique. Moreover, since the questions and the answer alternatives in the present survey in principle are identical to the corresponding ones in Graham and Harvey (2001), it is possible to compare the results in the present study with the results from U.S. companies. Brounen et al. (2004) used the very same questionnaire as Graham and Harvey (2001) when the use of methods in continental Europe was examined. The results in the present study are therefore also compared to the results in Brounen et al. (2004) ${ }^{6}$.

\section{$2.2 \quad$ Delivery and Response}

The survey was sent to the respondents by mail three times with response deadlines 8 January, 14 March and 23 May, 2005. Non-respondents during the first round were contacted by telephone. Of 244 surveys sent out,

\footnotetext{
${ }^{2}$ In some companies none of the senior executives at group or parent company level had the title "CFO", "financial manager" or "controller". In those cases CEOs were addressed since they were assumed to be responsible for financial management as well as traditional CEO tasks.

${ }^{3}$ This study was declared best paper in the Journal of Financial Economics in 2001 and is often cited in both academic journals and textbooks.

${ }^{4}$ Additional questions on capital structure and dividend policy are analysed in a separate study.

${ }^{5}$ Sandahl and Sjögren (2003) give a broad description of the use of capital budgeting techniques in Swedish companies but only study their relation to three company characteristics, and respondents were not asked how often methods were used (i.e. a nominal scale was used). Moreover, Sandahl and Sjögren (2003) examined the companies' discount rate level, but not the employment of cost of capital estimation methods. Holmén and Pramborg (2009) also surveyed Swedish companies but only focused on the use of capital budgeting methods for foreign direct investments. In addition, the overall response rate in the present study is $39,1 \%$, which is higher than in Sandahl and Sjögren (2003) and Holmén and Pramborg (2009) which obtained 24,4\% and 29,1\% response rates, respectively.

${ }^{6}$ Since other possible comparison studies were on different populations with different methods (e.g. Klammer, 1972; Gitman and Forrester, 1977; Gitman and Mercurio, 1982; Gitman and Maxwell, 1985; Trahan and Gitman, 1995; Liljeblom and Vaihekoski, 2004; Silvola, 2006; Trong et al., 2008), the author chose to mainly focus the comparisons to Graham and Harvey (2001) and Brounen et al. (2004), or as Pike (1996) puts it, "Every survey has some merit, telling us something of the practices at the date of survey for those responding firms. The problem arises when attempting to generalise such findings to a wider population and to identify discernible capital budgeting trends by means of comparison with earlier empirical studies".
} 
112 were returned which equals a response rate of $45,9 \% .7$ surveys were unusable and therefore not included in the statistical analysis, for an adjusted response rate of $43,0 \%$.

In 2008 the survey was sent four times with response deadlines of 18 February, 10 March, 3 April and 16 June. Again, non-respondents were contacted by telephone. Of 249 surveys sent out, 92 were returned, which equals a response rate of $36,9 \%$. Four questionnaires were unusable, for an adjusted response rate of $35,3 \%$.

When the two surveys are combined, the total adjusted response rate is $39,1 \%$. Graham and Harvey (2001) and Brounen et al. (2004) received a response rate of $9 \%$ and 5\%, respectively. The number of respondents in these two studies was 392 and 313, respectively. In this study the number of respondents was, in total, 193.

The non-response analysis shows that the respondents were generally representative of the overall population, with P/E-ratios, debt-to-assets-ratios, dividend pay-out levels and industry classifications (manufacturing/non manufacturing) not differing significantly from the whole population. However, the responding companies were somewhat larger in both 2005 and 2008, though only significantly bigger (at the 10\% level) in 2008. This slight size bias could potentially drive the results.

\subsection{Summary Statistics and Data Issues}

Responses conditional on eleven company characteristics - size, growth, leverage, dividend payment, industry, management ownership, CEO age, CEO tenure, CEO education, target debt ratio and foreign sales - were analysed. The company characteristics are operationalised and dichotomised below.

Adjusted accounting revenue was used to measure size with revenues up to one billion U.S. dollar (USD) considered "small" and revenues exceeding one billion USD considered "large". One billion dollars equals 7,9516 billion Swedish crowns (SEK). Since the results in this study (which are from 2005 and 2008) are primarily compared to the results of the U.S. study (which are from the beginning of 1999), adjustments have been made on the revenue figure for inflation in Sweden from the beginning of 1999 (January) ${ }^{7}$.

To proxy for growth, the price-earnings (P/E) ratio was used. Growth companies often have a high P/E. Those with 15 or above are considered "growth companies" and those with a P/E-ratio under 15 are considered "non-growth companies".

Negative P/E-ratios could also be associated with growth (since it is not uncommon that growth companies show negative profits and have share prices higher than zero), but comparison with Graham and Harvey (2001) and also Brounen et al. (2004) requires using the same standards.

Leverage was measured by the debt-to-asset ratio with above $30 \%$ considered "high leverage" and lower considered "low leverage".

A company is considered a dividend-paying company if it pays dividends. If no dividends are paid, it is considered as a non-dividend-paying company.

Data on the four company characteristics mentioned above - size, growth, leverage, and dividend payment are taken from Datastream ${ }^{8}$ for the years 2004 and $2007^{9}$.

\footnotetext{
${ }^{7}$ The Swedish Consumer Price Index (SCPI) was used to adjust the revenue figure. In January 1999, the SCPI was 256,2. In December 2004, the SCPI was 279,4, and in December 2007, the SCPI was 296,3. Thus, there has been an increase in the SCPI of (279,4256,2)/256,2 = 9,06\% between 1999 and 2005 and an increase in the SCPI of $(296,3-256,2) / 256,2=15,65 \%$ between 1999 and 2008. The Swedish companies' accounting revenues in 2004 and 2007 are therefore multiplied by 256,2/279,4 =91,696\% (rounded off to 92\%) and $256,2 / 296,3=86,466 \%$ (rounded off to $86 \%$ ), respectively. The adjusted revenue figure was then compared to how much 1 billion dollars equalled in SEK, on average, in 1998. The SEK/USD exchange rate was, on average, 7,9516 during 1998. Since one USD equalled 7,9516 SEK, "small companies" has an adjusted revenue range between 0-7,9516 billion SEK and "large companies" has an adjusted revenue exceeding 7,9516 billion SEK.

${ }^{8}$ In a few instances, when the data could not be collected from Datastream, it was collected directly from the annual reports.
} 
The company characteristic industry is dichotomised into "manufacturing industry" and "nonmanufacturing industry". The dichotomisation is based on Datastream industry classifications.

Management ownership was considered high if the top three officers owned 5\% or more of the company, if all options were exercised. Otherwise, given that the top three officers would own less than five percent of the company, if all options were exercised, management ownership was considered low.

Even though it is the CFO who employs the methods studied here, the CEO's age was requested since the CFO is seen as the CEO's agent. CEOs 50 or older were considered old - otherwise young. This variable differs from Graham and Harvey (2001) and Brounen et al. (2004) - where the breakpoint was 60 years old - because almost none of the Swedish CEO respondents were over 60, which made such a breakpoint meaningless.

Similarly, CEO tenure was considered long if the CEO had been in office for more than nine years otherwise short.

A degree of master (or higher) of science in business and economics was used as a proxy for CEO education in business and/or economics - another easy yes or no dichotomisation. In the U.S. and continental European studies, the proxy for CEO education in business or economics was whether or not the CEO had an MBA degree. The reason for the slightly different proxy choice in the present examination was that MBAs still are presumably less common in Sweden, especially compared with the U.S.

A target debt ratio was considered to exist unless the respondents claimed that they had a flexible debt range or no target at all.

Finally, foreign income was considered high if the proportion of total sales outside Sweden was $24 \%$ or more - otherwise low.

Table 1: Company Characteristics, Definitions, Source and Dichotomisation

\begin{tabular}{|c|c|c|c|c|}
\hline $\begin{array}{c}\text { Company } \\
\text { Characteristic }\end{array}$ & Definition & Source & Dichote & nisation \\
\hline Size & $\begin{array}{l}\text { Adjusted revenue figure of } 2004 \text { and } \\
2007 .\end{array}$ & Datastream. & $\begin{array}{l}\leq 7,9516 \text { billion } \text { SEK }= \\
\text { Small. }\end{array}$ & $\begin{array}{l}>7,9516 \text { billion } \mathrm{SEK}= \\
\text { Large. }\end{array}$ \\
\hline Growth & P/E-ratio at the end of 2004 and 2007. & Datastream. & $<15=$ Non-growth & $\geq 15=$ Growth \\
\hline Leverage & $\begin{array}{l}\text { Total debt to total assets at the end of } \\
2004 \text { and } 2007 \text {. }\end{array}$ & Datastream. & $\leq 30 \%=$ Low & $>30 \%=$ High \\
\hline Dividend Payment & Dividend payments in 2004 and 2007. & Datastream. & $\begin{array}{l}\text { Dividends are not paid } \\
\text { out }=\text { No. }\end{array}$ & $\begin{array}{l}\text { Dividends are paid out }= \\
\text { Yes. }\end{array}$ \\
\hline Industry & $\begin{array}{l}\text { A classification scheme based on each } \\
\text { company's principal activity. }\end{array}$ & Datastream. & $\begin{array}{l}\text { Given that certain } \\
\text { conditions are met = } \\
\text { Manufacturing company. }\end{array}$ & $\begin{array}{l}\text { Given that certain } \\
\text { conditions are met = } \\
\text { Non-manufacturing } \\
\text { company "Others". }\end{array}$ \\
\hline $\begin{array}{l}\text { Management } \\
\text { Ownership }\end{array}$ & $\begin{array}{l}\text { Portion of the company that would be } \\
\text { owned by the top three officers if all } \\
\text { options were exercised in } 2005 \text { and } \\
2008 \text {. }\end{array}$ & $\begin{array}{l}\text { Survey answers by } \\
\text { CFOs. }\end{array}$ & $<5 \%=$ Low & $\geq 5=$ High. \\
\hline CEO Age & $\begin{array}{l}\text { Age of the present CEO in } 2005 \text { and } \\
2008 \text {. }\end{array}$ & $\begin{array}{l}\text { Survey answers by } \\
\text { CFOs. }\end{array}$ & $<50=$ Young & $\geq 50=$ Old \\
\hline CEO Tenure & $\begin{array}{l}\text { Number of years the present CEO had } \\
\text { been working as the CEO in the } \\
\text { company in } 2005 \text { and } 2008 \text {. }\end{array}$ & $\begin{array}{l}\text { Survey answers by } \\
\text { CFOs. }\end{array}$ & $\leq 9$ years $=$ Short & $>=9$ years $=$ Long. \\
\hline $\begin{array}{l}\text { CEO Education in } \\
\text { Business and/or } \\
\text { Economics }\end{array}$ & $\begin{array}{l}\text { Whether or not the present CEO had a } \\
\text { masters in business and economics in } \\
2005 \text { and } 2008 \text {. }\end{array}$ & $\begin{array}{l}\text { Survey answers by } \\
\text { CFOs. }\end{array}$ & $\begin{array}{l}\text { CEO did not have a } \\
\text { masters in business and } \\
\text { economics }=\text { No. }\end{array}$ & $\begin{array}{l}\text { CEO had a masters in } \\
\text { business and economics } \\
=\text { Yes. }\end{array}$ \\
\hline Target Debt Ratio & Target debt ratio in 2005 and 2008. & $\begin{array}{l}\text { Survey answers by } \\
\text { CFOs. }\end{array}$ & $\begin{array}{l}\text { No target range or a } \\
\text { flexible target range }= \\
\text { No. }\end{array}$ & $\begin{array}{l}\text { Somewhat tight range or } \\
\text { strict target range }=\text { Yes. }\end{array}$ \\
\hline Foreign Income & $\begin{array}{l}\text { The portion of total sales that took place } \\
\text { outside Sweden in } 2005 \text { and } 2008 \text {. }\end{array}$ & $\begin{array}{l}\text { Survey answers by } \\
\text { CFOs. }\end{array}$ & $<24 \%=$ No. & $\geq 24 \%=$ Yes. \\
\hline
\end{tabular}

${ }^{9}$ The idea is that the independent variables from 2004 and 2007 could affect the dependent variables in 2005 and 2008 , respectively. 
The last six-mentioned company characteristics - management ownership, CEO age, CEO tenure, CEO education, target debt ratio and foreign income - are based on the answers in the survey. The eleven company characteristics in the present study ${ }^{10}$ - the chosen proxies, the source of chosen proxies, and finally the exact definition of how the proxies were dichotomised - are summarised in Table 1.

The values that were used to dichotomise the independent variables are (with the two exceptions already mentioned) identical to the ones that were used by Graham and Harvey (2001) and Brounen et al. (2004). This enables a comparison to the U.S. and continental European studies. Some independent variables in the U.S. study were, however, not used in the present study. The following four independent variables were included in Graham and Harvey (2001) but not in the present study - "regulated", "public corporation", "fortune 500 mailing" and "investment grade" 11 . None of the companies in the present study were regulated and all were public companies, so that variable was dropped. The "fortune 500" variable was specific for the U.S. study and not applicable in Sweden. The "investment grade" variable refers to a company's credit rating. In the U.S., the bond market is developed and is an important source of capital for many companies. In Sweden, however, when compared to the U.S., bank lending is a more common source of debt capital than bond issuances. For that reason, many Swedish-listed companies have not been rated by any of the biggest credit-rating agencies ${ }^{12}$. Since bank lending is a more important source of debt capital in Sweden than bond issuances, and a large portion of Swedish listed companies' debt has not been rated by any of the big three credit-rating agencies (Standard \& Poor's, Moody's and Fitch Ratings), the "investment grade" variable was also dropped. and Table 3).

Correlation between the eleven independent variables was investigated using phi coefficients (see Tables 2

The correlation coefficient matrices in Tables 2 and 3 suggest that small companies, as expected, were management owned and, moreover, that large companies paid dividends to a higher extent than small companies. Not surprisingly, manufacturing companies had more foreign income. Companies with less management ownership had CEOs with shorter tenure, while older CEOs had a longer tenure. The discussed correlations were found in both 2005 and 2008.

Even though some independent variables correlated, Tables 2 and 3 indicate that the multicollinearity problem - and the need to perform robustness checks - is limited. The highest correlation was 0,527 and most correlations were far lower. Robustness checks, where the results could be controlled for size or other independent variables, were therefore not conducted.

An independent samples t-test was conducted to analyse the answers to questions 1-3. Significant differences in the use of capital budgeting and cost of capital estimation methods, conditional on the eleven independent variables, are reported at the $p<0,01$ level, $p<0,05$ level and $p<0,1$ level. An independent samples ttest was also conducted to analyse changes over time (i.e., between 2005 and 2008). Again, significant changes are reported at the $p<0,01$ level, $p<0,05$ level and $p<0,1$ level.

\footnotetext{
${ }^{10}$ When different management control systems are discussed, it is common that the relationship between strategy and management control systems is studied (e.g., Langfield-Smith, 1997; Chenhall, 2003). The present study, however, instead focuses on the eleven mentioned non-strategy-based independent variables.

${ }^{11}$ Also one dependent variable was excluded; namely, the use of hurdle rates. Instead, the annuity method was included in the present studybecause (at the expense of the hurdle rate method) the author wanted to study changes, regarding of the use of capital budgeting techniques, over time in Sweden and the use of the annuity method had been included in prior Swedish studies.

${ }^{12}$ Standard \& Poor's, Moody's and Fitch Ratings publish credit ratings on their websites.
} 
Table 2: Correlations of Independent Variables from the 2005 Survey

\begin{tabular}{|c|c|c|c|c|c|c|c|c|c|c|}
\hline & Size & Growth & Leverage & Dividends & Industry & $\begin{array}{l}\text { Mgmt. } \\
\text { Own. }\end{array}$ & Target Debt Ratio & Foreign Income & CEO Master & CEO Age \\
\hline Size (Small to Large) & 1 & & & & & & & & & \\
\hline Growth (Low to High) & $-0,117$ & 1 & & & & & & & & \\
\hline Leverage (Low to High) & 0,082 & $-0,084$ & 1 & & & & & & & \\
\hline Dividends (No to Yes) & $0,343 * * *$ & 0,089 & 0,055 & 1 & & & & & & \\
\hline Industry (Non-manuf. to Man.) & $0,180^{*}$ & $-0,004$ & 0,015 & 0,060 & 1 & & & & & \\
\hline Management Own (Low to High) & $-0,240 * *$ & 0,144 & 0,140 & $-0,119$ & $-0,101$ & 1 & & & & \\
\hline Target Debt Ratio (No to Yes) & $-0,022$ & $-0,043$ & 0,096 & 0,129 & 0,037 & $-0,219 * *$ & 1 & & & \\
\hline Foreign Income (No to Yes) & 0,111 & $-0,019$ & 0,042 & 0,046 & $0,359 * * *$ & 0,107 & $-0,070$ & 1 & & \\
\hline CEO Master (No to Yes) & 0,050 & 0,042 & 0,096 & $-0,122$ & $-0,026$ & 0,082 & 0,022 & 0,015 & 1 & \\
\hline CEO Age (Young to Old) & 0,156 & 0,144 & 0,057 & 0,119 & $-0,037$ & $0,249 * *$ & $-0,135$ & 0,016 & $-0,184^{*}$ & 1 \\
\hline CEO Tenure (Short to Long) & $-0,105$ & 0,026 & 0,019 & $0,198 * *$ & 0,045 & $0,527 * * *$ & $-0,174 *$ & $0,199 * *$ & $-0,169$ & $0,283 * * *$ \\
\hline
\end{tabular}

CEO Tenure (Short to Long)

Tignificant at the $p<0,1$

Correlation is significant at the $p<0,05$ level (two-tailed).

* Correlation is significant at the $p<0,1$ level (two-tailed).

\begin{tabular}{|c|c|c|c|c|c|c|c|c|c|c|}
\hline & Size & Growth & Leverage & Dividends & Industry & $\begin{array}{c}\text { Mgmt. } \\
\text { Own. }\end{array}$ & Target Debt Ratio & Foreign Income & CEO Master & CEO Age \\
\hline Size (Small to Large) & 1 & & & & & & & & & \\
\hline Growth (Low to High) & 0,149 & 1 & & & & & & & & \\
\hline Leverage (Low to High) & 0,108 & 0,127 & 1 & & & & & & & \\
\hline Dividends (No to Yes) & $0,372 * * *$ & 0,024 & $0,203 *$ & 1 & & & & & & \\
\hline Industry (Non-manuf. to Man.) & 0,176 & $-0,042$ & $-0,071$ & 0,081 & 1 & & & & & \\
\hline Management Own (Low to High) & $-0,240 * *$ & 0,138 & 0,084 & $-0,179 *$ & $-0,051$ & 1 & & & & \\
\hline Target Debt Ratio (No to Yes) & 0,053 & 0,056 & $0,271 * *$ & $0,268 * *$ & $-0,100$ & $-0,086$ & 1 & & & \\
\hline Foreign Income (No to Yes) & 0,134 & $0,255 * *$ & $-0,087$ & 0,153 & $0,378 * * *$ & $-0,110$ & $-0,086$ & 1 & & \\
\hline CEO Master (No to Yes) & 0,005 & $-0,077$ & 0,040 & $-0,020$ & $-0,112$ & 0,086 & $-0,002$ & $-0,241 * *$ & 1 & \\
\hline CEO Age (Young to Old) & $0,296 * * *$ & $-0,044$ & $-0,023$ & 0,039 & 0,017 & 0,106 & 0,033 & 0,046 & $-0,130$ & 1 \\
\hline CEO Tenure (Short to Long) & $-0,114$ & 0,113 & $0,198^{*}$ & 0,052 & 0,061 & $0,433 * * *$ & $-0,060$ & 0,039 & 0,020 & $0,251 * *$ \\
\hline
\end{tabular}

*** Correlation is significant at the $p<0,01$ level (two-tailed).

** Correlation is significant at the $p<0,05$ level (two-tailed)

* Correlation is significant at the $p<0,1$ level (two-tailed). 


\section{COMPANIES' USE OF CAPITAL BUDGETING METHODS}

\subsection{The Dependent Variables}

As noted, financial management textbooks often recommend capital budgeting methods that discount cash flows; e.g., the NPV method. Brealey and Myers (2003), for example, have a chapter named "Why net present value leads to better investment decisions than other criteria" (Brealey and Myers, 2003; 90-117). Other methods, such as internal rate of return (IRR) and undiscounted pay-back, are often criticized. Since the use of these three and another nine capital budgeting methods are examined, a brief description of the theoretical merits and drawbacks of the methods is as follows:

1. NPV is often recommended on theoretical grounds since it incorporates all cash flows generated by an investment while taking the time value of money into account.

2. IRR is, in most cases, theoretically preferable, but it can be misleading when management must choose from among mutually exclusive projects because of so-called multiple rates of return; so it is often not recommended.

3. Simple (undiscounted) payback does not consider the time-value of money and ignores cash flows subsequent to the maximum payback period (defined by management); so is also not recommended.

4. Discounted payback has one advantage over undiscounted payback - it does not ignore the time value of money. Nevertheless, it still ignores cash flows subsequent to the maximum payback period and is therefore not recommended.

5. The earnings multiple approach $(\mathrm{P} / \mathrm{E})$ can be seen as a version of payback since it indicates how many years it takes until the initial investment (share price) has been repaid by earnings. This method can be considered as unsophisticated since it

a. considers earnings instead of cash flows

b. does not take the time value of money into consideration

c. only considers one earnings figure (instead of many). This relative valuation method, on the other hand, has the advantage of letting the more-or-less-efficient capital market guide the decision-maker in the valuation process. This method is, nevertheless, often not recommended because of its described theoretical shortcomings.

6. The main disadvantage with accounting rate of return (ARR) is that it uses accounting numbers (instead of cash flows) and, again, does not consider the time value of money; so it is not recommended.

7. Sensitivity analysis which, in principle, has no real drawbacks and is therefore recommended, is done in order to see if an investment would still be profitable if one or more variables changed.

8. It has been suggested that the reason why projects - that at first glance look unprofitable - are made is that management explicitly or implicitly considers the possibility to make subsequent investments conditional on the current project. This possibility/opportunity is called a real option. To estimate the value of real options should, in principle, not have any drawbacks and is therefore recommended.

9. Value-at-risk (VAR) is a rather new and often recommended method and is defined as measuring "...the worst loss over a target horizon that will not be exceeded with a given level of confidence" (Jorion, 2006; viii). One disadvantage with this method is that it does not estimate how bad the loss might be when market conditions are not normal.

10. Profitability index indicates the highest NPV per monetary unit of initial outlay and is often recommended. However, when investment projects are indivisible, it could also be important to keep an eye on the absolute NPV so that investments with high NPV per monetary unit, but lower absolute NPV, are not chosen over investments with lower NPV per monetary unit but with higher absolute NPV.

11. Adjusted present value (APV) adds the value of the financial side effects of an investment to the NPV and should, in principle, have no theoretical shortcomings; it is therefore recommended.

12. The annuity-method is a variant of the NPV method. If you know the annuity of an investment and how many years the investment generates net cash-inflows or net cash-outflows, then you can easily calculate the NPV of the investment by discounting the annuities with the relevant weighted average cost of capital (WACC). 


\subsection{Results}

\subsubsection{The Relation between Company Characteristics and Use of Capital Budgeting Methods}

Tables 4 and 5 show that the respondents mostly utilised NPV (59\% in 2005 and 64\% in 2005) and payback (57\% in 2005 and 51\% in 2008). The third most popular method was sensitivity analysis (43\% in 2005 and $48 \%$ in 2008).

The results suggest that larger companies used capital budgeting methods, sophisticated as well as unsophisticated, more frequently than did smaller ones in both 2005 and 2008. Discounting-based techniques (NPV, IRR, discounted pay back and sensitivity analysis ${ }^{13}$ ) were significantly more used in larger companies in 2005 . In 2008, larger companies still employed discounting-based methods more often than smaller companies, but the differences were not significant. This could potentially indicate that the difference between larger and smaller companies is reduced (i.e., they are converging). The only capital budgeting method that was employed significantly more often by large companies in 2005 and 2008 was VAR. Finally, one method (undiscounted), payback, was used more often by larger companies in both years, but only significantly more in 2008.

In 2008, growth companies reported using the profitability index significantly more often than non-growth companies. The reason could be that growth companies often can choose among many projects and therefore must choose the projects with the highest NPV per monetary unit of initial outlay. In 2005, however, the result was reversed (but not statistically significant).

Not surprisingly, undiscounted payback is more popular among companies with a high amount of debt. The rationale for this could be that high financial leverage, which often is equivalent to high fixed cash outflows, all other things held constant, puts management under pressure to invest in projects that quickly give a return in the form of positive cashflows. Projects with a quicker pay-back time are generally "front loaded" which reduces business risk (in contrast to more risky "rear loaded" investments). A reduced business risk could be relatively more "valuable" in companies with more financial risk since the total risk (i.e., business risk plus financial risk) otherwise could get too high. It has been argued that a higher amount of debt could motivate organisational efficiency (Jensen, 1986), but higher financial leverage could, on the other hand, also (except for higher bankruptcy costs) possibly lead to more investment myopia (i.e., use of payback). High-leverage companies used the undiscounted payback method (and also the APV and annuity method) more often both years, but only significantly more in 2008.

CEO-education did not lead to a more frequent use of sophisticated methods. If, instead, the questions would have targeted the CFO, the results may have been different. It is probably the CFO (rather than the CEO) who chooses the methods asked for in this survey. Thus, the possible education effect could possibly have been made visible if the questions would have concerned the status of the CFO and not the CEO. Moreover, CEO age and CEO tenure only had limited effects on the method choices. In both 2005 and 2008, there were negative relations between CEO age and use of sensitivity analysis, on the one hand, and CEO tenure and employment of the earnings multiple approach on the other. The results were, however, only significantly negative in 2008. One reason for why companies with younger CEOs used sensitivity analyses more often might be that younger CEOs have less informal authority (because of the age difference between the CEO and the members of the board) and therefore feel obliged to anchor proposed investments with good arguments. Otherwise the board, which must approve big strategic investment decisions, might not accept the proposed investment project. CEOs with shorter tenure might prefer the earnings multiple approach since they feel less certain than CEOs with longer tenures how to value a potential investment. By using the current average market multiple, the CEO will (approximately) come up with the same value, as the capital market would. Thus by using the earnings multiple approach, the relatively inexperienced CEO reduces the probability that the value of the investment is either overstated or understated. Nevertheless, as with education, the impact of age and tenure could have been different if the questions had concerned the status of the CFO.

\footnotetext{
${ }^{13}$ Naturally, a non-complete sensitivity analysis does not have to include a discounting element. In a complete sensitivity analysis, however, all important variables (including the discount rate) should be included and as a starting point these variables should have their most probable values. Then the "output" should be observed when the values of these variables are altered.
}

(C) 2012 The Clute Institute http://www.cluteinstitute.com/ 
Interestingly, ARR seemed to be more common among companies with a target debt ratio. It could be that because of the accounting-related goal; i.e., the target debt ratio, the decision whether or not to make an investment was not just based on economics, but also on accounting.

Table 4: The Use of Capital Budgeting Methods in Swedish-listed Companies in 2005

\begin{tabular}{|c|c|c|c|c|c|c|c|c|c|c|}
\hline \multirow[b]{2}{*}{$\begin{array}{l}\text { Type of Capital Budgeting } \\
\text { Method }\end{array}$} & \multirow[b]{2}{*}{$\begin{array}{l}\text { Use } \\
\%^{14}\end{array}$} & \multirow[b]{2}{*}{ Mean } & \multicolumn{2}{|c|}{ Size } & \multicolumn{2}{|c|}{$\mathbf{P} / \mathbf{E}$} & \multicolumn{2}{|c|}{ Leverage } & \multicolumn{2}{|c|}{ Pay Dividends } \\
\hline & & & Small & Large & Growth & $\begin{array}{c}\text { Non- } \\
\text { growth }\end{array}$ & Low & High & Yes & No \\
\hline a) NPV & 59,0 & 2,50 & 2,35 & $3,00 * *$ & 2,43 & 2,53 & 2,44 & 2,64 & 2,59 & 2,37 \\
\hline b) IRR & 33,3 & 1,57 & 1,33 & $2,38 * * *$ & 1,68 & 1,51 & 1,47 & 1,86 & 1,85 & $1,22 * *$ \\
\hline c) Annuity & 2,9 & 0,37 & 0,37 & 0,38 & 0,27 & 0,43 & 0,36 & 0,39 & 0,42 & 0,30 \\
\hline d) Earnings Multiple (P/E) & 28,6 & 1,36 & 1,33 & 1,46 & 1,30 & 1,40 & 1,30 & 1,54 & 1,29 & 1,46 \\
\hline e) APV & 8,6 & 0,56 & 0,54 & 0,63 & 0,35 & 0,68 & 0,49 & 0,75 & 0,46 & 0,70 \\
\hline f) Payback & 57,1 & 2,39 & 2,27 & 2,79 & 2,51 & 2,32 & 2,29 & 2,68 & 2,41 & 2,37 \\
\hline g) Discounted Payback & 21,0 & 1,08 & 0,81 & $1,96 * * *$ & 1,00 & 1,12 & 1,09 & 1,04 & 1,32 & $0,76^{* *}$ \\
\hline h) Profitability Index & 13,3 & 0,69 & 0,77 & 0,42 & 0,59 & 0,74 & 0,65 & 0,79 & 0,75 & 0,61 \\
\hline i) ARR & 25,7 & 1,14 & 1,09 & 1,33 & 0,86 & 1,29 & 1,19 & 1,00 & 1,29 & 0,96 \\
\hline j) Sensitivity Analysis & 42,9 & 1,92 & 1,78 & $2,42 *$ & 1,70 & 2,04 & 1,90 & 2,00 & 1,93 & 1,91 \\
\hline k) VAR & 4,8 & 0,34 & 0,26 & $0,63 *$ & 0,38 & 0,32 & 0,29 & 0,50 & 0,39 & 0,28 \\
\hline \multirow[t]{2}{*}{ 1) Real Options } & 1,8 & 0,19 & 0,15 & 0,33 & 0,14 & 0,22 & 0,14 & 0,32 & 0,22 & 0,15 \\
\hline & & & \multicolumn{2}{|c|}{ Industry } & \multicolumn{2}{|c|}{ Management Own } & \multicolumn{2}{|c|}{ CEO Age } & \multicolumn{2}{|c|}{ CEO Tenure } \\
\hline $\begin{array}{c}\text { Type of Capital Budgeting } \\
\text { Method }\end{array}$ & $\begin{array}{c}\text { Use } \\
\%\end{array}$ & Mean & Manuf. & Others & Low & High & Old & Young & Long & Short \\
\hline a) NPV & 59,0 & 2,50 & 2,55 & 2,46 & 2,58 & 2,06 & 2,62 & 2,36 & 2,38 & 2,52 \\
\hline b) IRR & 33,3 & 1,57 & 1,93 & $1,35^{*}$ & 1,62 & 1,50 & 1,84 & $1,28^{*}$ & 2,05 & 1,47 \\
\hline c) Annuity & 2,9 & 0,37 & 0,28 & 0,43 & 0,39 & 0,50 & 0,29 & 0,46 & 0,48 & 0,35 \\
\hline d) Earnings Multiple (P/E) & 28,6 & 1,36 & 1,05 & 1,55 & 1,49 & 0,94 & 1,42 & 1,30 & 1,10 & 1,45 \\
\hline e) APV & 8,6 & 0,56 & 0,25 & $0,75^{* *}$ & 0,59 & 0,63 & 0,62 & 0,50 & 0,62 & 0,55 \\
\hline f) Payback & 57,1 & 2,39 & 2,75 & $2,17 * *$ & 2,35 & 2,38 & 2,42 & 2,36 & 2,71 & 2,34 \\
\hline g) Discounted Payback & 21,0 & 1,08 & 1,43 & $0,86^{*}$ & 1,13 & 0,75 & 1,15 & 1,00 & 1,24 & 1,05 \\
\hline h) Profitability Index & 13,3 & 0,69 & 0,35 & $0,98 * *$ & 0,73 & 0,56 & 0,65 & 0,72 & 0,38 & 0,77 \\
\hline i) ARR & 25,7 & 1,14 & 0,90 & 1,29 & 1,28 & 0,75 & 1,22 & 1,06 & 0,76 & 1,20 \\
\hline j) Sensitivity Analysis & 42,9 & 1,92 & 2,03 & 1,86 & 2,10 & $1,31 *$ & 1,87 & 1,98 & 1,76 & 1,99 \\
\hline k) VAR & 4,8 & 0,34 & 0,25 & 0,40 & 0,39 & 0,19 & 0,44 & 0,24 & 0,29 & 0,36 \\
\hline \multirow[t]{2}{*}{ 1) Real Options } & 1,8 & 0,19 & 0,13 & 0,23 & 0,19 & 0,31 & 0,18 & 0,20 & 0,24 & 0,18 \\
\hline & & & \multicolumn{2}{|c|}{ CEO Master } & \multicolumn{2}{|c|}{ Target Debt Ratio } & \multicolumn{2}{|c|}{ Foreign Sales } & & \\
\hline $\begin{array}{l}\text { Type of Capital Budgeting } \\
\text { Method }\end{array}$ & $\begin{array}{c}\text { Use } \\
\%\end{array}$ & Mean & Yes & No & No & Yes & Yes & No & & \\
\hline a) NPV & 59,0 & 2,50 & 2,72 & 2,43 & 2,37 & 2,73 & 2,51 & 2,43 & & \\
\hline b) IRR & 33,3 & 1,57 & 1,83 & 1,53 & 1,48 & 1,76 & 1,69 & 1,14 & & \\
\hline c) Annuity & 2,9 & 0,37 & 0,28 & 0,45 & 0,32 & 0,46 & 0,32 & 0,62 & & \\
\hline d) Earnings multiple (P/E) & 28,6 & 1,36 & 1,42 & 1,51 & 1,49 & 1,24 & 1,32 & 1,43 & & \\
\hline e) APV & 8,6 & 0,56 & 0,50 & 0,66 & 0,67 & 0,46 & 0,59 & 0,52 & & \\
\hline f) Payback & 57,1 & 2,39 & 2,31 & 2,43 & 2,43 & 2,46 & 2,52 & 2,14 & & \\
\hline g) Discounted Payback & 21,0 & 1,08 & 1,28 & 1,08 & 1,13 & 1,08 & 1,16 & 0,90 & & \\
\hline h) Profitability Index & 13,3 & 0,69 & 0,58 & 0,85 & 0,62 & 0,89 & 0,49 & $1,38 * * *$ & & \\
\hline i) ARR & 25,7 & 1,14 & 1,11 & 1,09 & 0,92 & $1,51 *$ & 1,02 & 1,43 & & \\
\hline j) Sensitivity Analysis & 42,9 & 1,92 & 1,97 & 2,09 & 1,94 & 2,03 & 1,99 & 1,71 & & \\
\hline k) VAR & 4,8 & 0,34 & 0,36 & 0,32 & 0,35 & 0,38 & 0,27 & 0,62 & & \\
\hline 1) Real Options & 1,8 & 0,19 & 0,19 & 0,23 & 0,19 & 0,22 & 0,17 & 0,29 & & \\
\hline
\end{tabular}

\footnotetext{
${ }^{14}$ Respondents who answered that they "always" (represented by the highest score - 4) or "almost always" (represented by 3 ) used a method are defined as "users" of that method.
} 
Table 5: The Use of Capital Budgeting Methods in Swedish-listed Companies in 2008

\begin{tabular}{|c|c|c|c|c|c|c|c|c|c|c|}
\hline \multirow[b]{2}{*}{$\begin{array}{c}\text { Type of Capital Budgeting } \\
\text { Method }\end{array}$} & \multirow[b]{2}{*}{$\begin{array}{l}\text { Use } \\
\%^{15}\end{array}$} & \multirow[b]{2}{*}{ Mean } & \multicolumn{2}{|c|}{ Size } & \multicolumn{2}{|c|}{$\mathbf{P} / \mathbf{E}$} & \multicolumn{2}{|c|}{ Leverage } & \multicolumn{2}{|c|}{ Pay Dividends } \\
\hline & & & Small & Large & Growth & $\begin{array}{l}\text { Non- } \\
\text { growth }\end{array}$ & Low & High & Yes & No \\
\hline a) NPV & 63,6 & 2,55 & 2,45 & 2,86 & 2,43 & 2,60 & 2,46 & 2,72 & 2,69 & 2,30 \\
\hline b) IRR & 26,1 & 1,27 & 1,25 & 1,33 & 0,97 & 1,43 & 1,12 & 1,59 & 1,44 & 1,00 \\
\hline c) Annuity & 3,4 & 0,38 & 0,40 & 0,29 & 0,40 & 0,36 & 0,25 & $0,62 * *$ & 0,44 & 0,27 \\
\hline d) Earnings Multiple (P/E) & 27,3 & 1,40 & 1,39 & 1,48 & 1,17 & 1,53 & 1,47 & 1,28 & 1,40 & 1,42 \\
\hline e) APV & 4,5 & 0,47 & 0,45 & 0,52 & 0,33 & 0,53 & 0,34 & $0,72 *$ & 0,42 & 0,55 \\
\hline f) Payback & 51,1 & 2,20 & 2,01 & $2,81 * *$ & 2,47 & 2,07 & 2,00 & $2,62 *$ & 2,53 & $1,67 * * *$ \\
\hline g) Discounted Payback & 12,5 & 0,74 & 0,69 & 0,90 & 0,63 & 0,79 & 0,59 & 1.03 & 0,85 & 0,55 \\
\hline h) Profitability Index & 11,4 & 0,72 & 0,67 & 0,86 & 1,13 & $0,50 * *$ & 0,75 & 0,66 & 0,73 & 0,70 \\
\hline i) ARR & 21,6 & 1,05 & 0,97 & 1,29 & 0,90 & 1,12 & 0,98 & 1.17 & 1,42 & $0,42 * * *$ \\
\hline j) Sensitivity Analysis & 47,7 & 2,05 & 1,93 & 2,43 & 1,83 & 2,16 & 2,00 & 2,14 & 2,13 & 1,91 \\
\hline k) VAR & 9,1 & 0,60 & 0,46 & $1,05 * *$ & 0,43 & 0,69 & 0,47 & 0,86 & 0,78 & $0,30 * *$ \\
\hline \multirow[t]{2}{*}{ 1) Real Options } & 2,3 & 0,26 & 0,27 & 0,24 & 0,13 & 0,33 & 0,32 & 0,14 & 0,27 & 0,24 \\
\hline & & & \multicolumn{2}{|c|}{ Industry } & \multicolumn{2}{|c|}{ Management Own } & \multicolumn{2}{|c|}{ CEO Age } & \multicolumn{2}{|c|}{ CEO Tenure } \\
\hline $\begin{array}{c}\text { Type of Capital Budgeting } \\
\text { Method }\end{array}$ & $\begin{array}{c}\text { Use } \\
\%\end{array}$ & Mean & Manuf. & Others & Low & High & Old & Young & Long & Short \\
\hline a) NPV & 63,6 & 2,55 & 2,49 & 2,59 & 2,51 & 2,71 & 2,40 & 2,67 & 2,20 & 2,59 \\
\hline b) IRR & 26,1 & 1,27 & 1,38 & 1,20 & 1,28 & 1,21 & 1,05 & 1,46 & 1,30 & 1,27 \\
\hline c) Annuity & 3,4 & 0,38 & 0,22 & 0,49 & 0,38 & 0,36 & 0,25 & 0,48 & 0,50 & 0,36 \\
\hline d) Earnings Multiple (P/E) & 27,3 & 1,40 & 1,27 & 1,51 & 1,49 & 1,00 & 0,90 & $1,83 * * *$ & 0,50 & $1,53 *$ \\
\hline e) APV & 4,5 & 0,47 & 0,30 & 0,59 & 0,42 & 0,71 & 0,33 & 0,58 & 0,60 & 0,45 \\
\hline f) Payback & 51,1 & 2,20 & 2,27 & 2,16 & 2,30 & 1,71 & 2,10 & 2,29 & 1,80 & 2,26 \\
\hline g) Discounted Payback & 12,5 & 0,74 & 0,73 & 0,75 & 0,72 & 0,86 & 0,57 & 0,88 & 0,60 & 0,76 \\
\hline h) Profitability Index & 11,4 & 0,72 & 0,38 & $0,96 * *$ & 0,69 & 0,86 & 0,70 & 0,73 & 0,70 & 0,72 \\
\hline i) $\mathrm{ARR}$ & 21,6 & 1,05 & 0,81 & 1,22 & 1,19 & $0,29 * *$ & 1,10 & 1,00 & 1,00 & 1,05 \\
\hline j) Sensitivity Analysis & 47,7 & 2,05 & 2,11 & 2,00 & 2,12 & 1,64 & 1,65 & $2,38 * *$ & 1,40 & 2,13 \\
\hline k) VAR & 9,1 & 0,60 & 0,54 & 0,65 & 0,66 & 0,29 & 0,68 & 0,54 & 0,70 & 0,59 \\
\hline \multirow[t]{2}{*}{ 1) Real Options } & 2,3 & 0,26 & 0,27 & 0,25 & 0,31 & 0,00 & 0,15 & 0,35 & 0,10 & 0,28 \\
\hline & & & \multicolumn{2}{|c|}{ CEO Master } & \multicolumn{2}{|c|}{ Target Debt Ratio } & \multicolumn{2}{|c|}{ Foreign Sales } & & \\
\hline $\begin{array}{c}\text { Type of Capital Budgeting } \\
\text { Method }\end{array}$ & $\begin{array}{c}\text { Use } \\
\%\end{array}$ & Mean & Yes & No & No & Yes & Yes & No & & \\
\hline a) NPV & 63,6 & 2,55 & 2,43 & 2,65 & 2,56 & 2,53 & 2,52 & 2,64 & & \\
\hline b) IRR & 26,1 & 1,27 & 1,57 & $1,00^{*}$ & 1,20 & 1,38 & 1,27 & 1,27 & & \\
\hline c) Annuity & 3,4 & 0,38 & 0,48 & 0,28 & 0,33 & 0,44 & 0,29 & $0,64 *$ & & \\
\hline d) Earnings Multiple (P/E) & 27,3 & 1,40 & 1,74 & $1,11 *$ & 1,61 & 1,09 & 1,32 & 1,68 & & \\
\hline e) APV & 4,5 & 0,47 & 0,55 & 0,39 & 0,48 & 0,44 & 0,41 & 0,64 & & \\
\hline f) Payback & 51,1 & 2,20 & 2,38 & 2,04 & 2,00 & 2,53 & 2,33 & 1,82 & & \\
\hline g) Discounted Payback & 12,5 & 0,74 & 1,12 & $0,39 * * *$ & 0,70 & 0,79 & 0,65 & 1,00 & & \\
\hline h) Profitability Index & 11,4 & 0,72 & 0,88 & 0,57 & 0,65 & 0,82 & 0,67 & 0,86 & & \\
\hline i) ARR & 21,6 & 1,05 & 1,24 & 0,87 & 0,81 & $1,41^{*}$ & 0,94 & 1,36 & & \\
\hline j) Sensitivity Analysis & 47,7 & 2,05 & 2,24 & 1,87 & 2,00 & 2,12 & 2,02 & 2,14 & & \\
\hline k) VAR & 9,1 & 0,60 & 0,74 & 0,48 & 0,63 & 0,56 & 0,48 & $0,95 *$ & & \\
\hline 1) Real Options & 2,3 & 0,26 & 0,24 & 0,28 & 0,24 & 0,29 & 0,29 & 0,18 & & \\
\hline
\end{tabular}

\footnotetext{
${ }^{15}$ Respondents who answered that they "always" (represented by the highest score - 4) or "almost always" (represented by 3 ) used a method are defined as "users" of that method.
} 
Management-owned companies calculated ARR less often in both years, but only significantly less in 2008. It could be that management-owned companies were less interested in how investments affect accounting numbers since the information between the top managers and the board/owners most likely is less asymmetrically distributed in management-owned companies (Jensen and Meckling, 1976). Because of the smaller gap between ownership and control and the subsequent more symmetrical distribution of information, it is less likely that top managers are motivated (and if they are, they get the opportunity) to engage in opportunistic earnings management. Kim and Yi (2006), for example, showed that a smaller ownership-control wedge leads to less opportunistic earnings management. If top managers in management-owned companies put less effort in managing earnings opportunistically, they could also potentially put less emphasis on estimating how investments affect the accounting numbers. Moreover, management-owned companies also employed the sensitivity analysis less often in both years, but only significantly less in 2005.

The results suggest that industry had an effect on the method choices in 2005 but generally not in 2008 (except for profitability index which was used significantly more by non-manufactures in both years). This could indicate that manufacturing and non-manufacturing companies used capital budgeting methods more similar (with regard to frequency) in 2008 than in 2005.

Finally, dividend-paying companies and those with limited or no foreign sales seemed to be using capital budgeting methods more frequently.

\subsubsection{Changes Over Time in Swedish Companies' Use of Capital Budgeting Methods}

Previous Swedish data (Renck, 1966; Tell, 1978; Yard, 1987; Andersson, 1994; Segelod, 1995) have, with the exception of Sandahl and Sjögren (2003) and Holmén and Pramborg (2009), not analysed responses conditional on firm characteristics; only mean values for entire samples are available. Previous studies are also not fully comparable since different types of companies were studied using different research methods (interviews, surveys and company manuals) focused on different questions, such as the use of capital budgeting methods at different hierarchical levels in the company (i.e., sometimes in connection with strategic, sometimes other more repetitive investments). Despite these shortcomings, a rough analysis of changes over time is possible to conduct. One interesting finding is that the use of NPV increased from 11\% (Renck, 1966) to 59\% in 2005 and 64\% in 2008 (see Table 6). The use of the not so theoretically appealing IRR seems to have declined. Undiscounted payback was, by far, the most popular technique in the 1960s and still remains quite popular though the data in the present study may indicate a decline. Moreover, all previous studies suggest that many different methods are utilised concurrently. The present study confirms those results.

The use of accounting ratio increased from 3-4\% (Renck, 1966; Tell, 1978; Andersson, 1994) to over 20\% in the present study, though declining a bit from 2005 to 2008. A possible reason for the increased employment of both NPV and accounting-based methods is that the current corporate governance regime is more shareholder valueoriented than previously. It is important for management to employ NPV since the utilisation of the method is supposed to affect shareholder value positively. At the same time, because of the focus on quarterly earnings and other accounting related measures, top management wants to make sure that the investments do not have any major short-term negative effects on the accounting numbers. Graham et al. (2005), for example, documented that because of the severe capital market reaction to missing an earnings target, companies could sacrifice real economic value in order to meet a short-term earnings target. 
Table 6: The Use of Capital Budgeting Methods from the 1960s until $2008^{16}$

\begin{tabular}{|c|c|c|c|c|c|c|c|c|c|c|c|c|c|c|}
\hline \multirow{5}{*}{$\begin{array}{c}\text { Type of Capital } \\
\text { Budgeting Method }\end{array}$} & \multicolumn{14}{|c|}{ Use in \% } \\
\hline & \multirow{2}{*}{\multicolumn{9}{|c|}{ Sweden }} & \multirow{4}{*}{$\begin{array}{c}\text { U.S. } \\
\text { Graham } \\
\text { \& } \\
\text { Harvey } \\
\text { (2001) } \\
\end{array}$} & \multirow{2}{*}{\multicolumn{4}{|c|}{$\begin{array}{l}\text { Continental Europe }^{17} \\
\text { Brounen et al. (2004) }\end{array}$}} \\
\hline & & & & & & & & & & & & & & \\
\hline & \multirow{2}{*}{$\begin{array}{l}\text { Renck } \\
(1966)\end{array}$} & \multirow{2}{*}{$\begin{array}{c}\text { Tell } \\
(\mathbf{1 9 7 8})\end{array}$} & \multirow{2}{*}{$\begin{array}{c}\text { Yard } \\
(1987)\end{array}$} & \multirow{2}{*}{$\begin{array}{c}\text { Andersson } \\
\text { (1994) }\end{array}$} & \multirow{2}{*}{$\begin{array}{c}\text { Segelod } \\
(\mathbf{1 9 9 5})\end{array}$} & \multirow{2}{*}{$\begin{array}{c}\text { Sandahl } \\
\text { \& Sjögren } \\
(\mathbf{2 0 0 3})^{18}\end{array}$} & \multirow{2}{*}{$\begin{array}{r}\text { Holmén \& } \\
\text { Pramborg } \\
(2009)^{19} \\
\end{array}$} & \multicolumn{2}{|c|}{$\begin{array}{c}\begin{array}{c}\text { The Present } \\
\text { Study }\end{array} \\
\end{array}$} & & \multirow[b]{2}{*}{ U.K. } & \multirow{2}{*}{$\begin{array}{l}\text { Nether- } \\
\text { lands }\end{array}$} & \multirow[b]{2}{*}{ Germany } & \multirow[b]{2}{*}{ France } \\
\hline & & & & & & & & $(\mathbf{2 0 0 5})$ & $(\mathbf{2 0 0 8 )}$ & & & & & \\
\hline Payback & $78,6 \%$ & $87 \%$ & 78,8 & $75 \%$ & $100 \%$ & $78,1 \%$ & $57 \%$ & $57 \%$ & $51 \%$ & $57 \%$ & $69 \%$ & $65 \%$ & $50 \%$ & $51 \%$ \\
\hline NPV & $10,7 \%$ & $33 \%$ & 37,6 & $16 \%$ & $52 \%$ & $52,3 \%$ & $49 \%$ & $59 \%$ & $64 \%$ & $75 \%$ & $47 \%$ & $70 \%$ & $48 \%$ & $35 \%$ \\
\hline IRR & $53,6 \%$ & $53 \%$ & 33,8 & $17 \%$ & $45 \%$ & $22,7 \%$ & $34 \%$ & $33 \%$ & $26 \%$ & $76 \%$ & $53 \%$ & $56 \%$ & $42 \%$ & $44 \%$ \\
\hline Annuity & $25,0 \%$ & $10 \%$ & & $2 \%$ & $14 \%$ & $10,2 \%$ & & $3 \%$ & $3 \%$ & & & & & \\
\hline Accounting Ratios & $3,6 \%$ & $3 \%$ & & $4 \%$ & & $21,1 \%$ & $38 \%$ & $26 \%$ & $22 \%$ & $20 \%$ & $38 \%$ & $25 \%$ & $32 \%$ & $16 \%$ \\
\hline Sensitivity Analysis & & & & & & & & $43 \%$ & $48 \%$ & $52 \%$ & $43 \%$ & $37 \%$ & $28 \%$ & $10 \%$ \\
\hline $\mathbf{P} / \mathbf{E}$ & & & & & & & $37 \%$ & $29 \%$ & $27 \%$ & $39 \%$ & $39 \%$ & $27 \%$ & $21 \%$ & $33 \%$ \\
\hline Discounted Payback & & & & & & & & $21 \%$ & $13 \%$ & $30 \%$ & $25 \%$ & $25 \%$ & $31 \%$ & $11 \%$ \\
\hline Real Options & & & & & & & $2 \%$ & $2 \%$ & $2 \%$ & $27 \%$ & $29 \%$ & $35 \%$ & $44 \%$ & $53 \%$ \\
\hline VAR & & & & & & & & $5 \%$ & $9 \%$ & $14 \%$ & $15 \%$ & $4 \%$ & $1 \%$ & $2 \%$ \\
\hline APV & & & & & & & & $9 \%$ & $5 \%$ & $12 \%$ & $14 \%$ & $8 \%$ & $8 \%$ & $15 \%$ \\
\hline Profitability Index & & & & & & & & $13 \%$ & $11 \%$ & $11 \%$ & $16 \%$ & $8 \%$ & $16 \%$ & $38 \%$ \\
\hline Total Use & & & & & & & & $297 \%$ & $278 \%$ & $413 \%$ & $388 \%$ & $360 \%$ & $321 \%$ & $308 \%$ \\
\hline
\end{tabular}

\footnotetext{
${ }^{16}$ The percentage figures from previous Swedish studies are, with the exception of Holmén and Pramborg (2009), from Sandahl and Sjögren (2003). As noted in the present study and in the U.S. and continental European studies, the respondents who answered that they "always" (represented by the highest score, 4) or "almost always" (represented by the second highest score, 3 ) use a method are defined as "users" of a specific method.

${ }^{17}$ For simplicity, the study is referred to as "continental European" even though U.K. is included.

${ }^{18}$ The survey data in Sandahl and Sjögren (2003) was from year 2000.

${ }^{19}$ The survey data in Holmén and Pramborg (2009) was from year 2003.

${ }^{20}$ The annuity-method is not included in the total-usefigure. If the annuity-method had been included, the total-usefigures in the present study would have been $300 \%$ in 2005 and $281 \%$ in 2008. The annuity-method was excluded to make comparison with the U.S. and continental European studies as fair as possible.

C 2012 The Clute Institute http://www.cluteinstitute.com/ 
A finer comparison of changes in mean values between 2005 and 2008 is possible to conduct since the same survey instrument has been used both years. Changes in use of capital budgeting methods between 2005 and 2008 were small (see Table 7), with the only statistically significant differences being a decline in discounted payback and an increase in VAR. Use of most other recommended methods also increased and most other nonrecommended methods declined. This pattern; i.e., a more sophisticated use over time, is also apparent over the longer term on Table 6, consistent with trends in other countries i.e. (e.g. Klammer and Walker, 1984; Pike, 1989, 1996; Arnold and Hatzopoulos, 2000; Ryan and Ryan, 2002; Bennouna et al., 2010).

Table 7: Changes in Use of Capital Budgeting Methods by Swedish-listed Companies between 2005 and 2008

\begin{tabular}{|l|c|c|c|l|}
\hline \multicolumn{1}{|c|}{ Method } & $\begin{array}{c}\text { Mean Values } \\
\mathbf{2 0 0 5}\end{array}$ & $\begin{array}{c}\text { Mean Values } \\
\mathbf{2 0 0 8}\end{array}$ & $\begin{array}{c}\text { Change between 2005 and 2008: + } \\
\text { Denotes Increase - Decrease }\end{array}$ & $\begin{array}{c}\text { Recommended or Not } \\
\text { by Textbooks }\end{array}$ \\
\hline a) NPV & 2,50 & 2,55 & + & Recommended \\
\hline b) IRR & 1,57 & 1,27 & - & Not recommended \\
\hline c) Annuity & 0,37 & 0,38 & + & Recommended \\
\hline d) Earnings Multiple (P/E) & 1,36 & 1.41 & + & Not recommended \\
\hline e) APV & 0,56 & 0,47 & - & Recommended \\
\hline f) Payback & 2,39 & 2,20 & - & Not recommended \\
\hline g) Discounted Payback & 1,08 & $0,74^{*}$ & - & Ret recommended \\
\hline h) Profitability Index & 0,69 & 0,72 & + & Not recommended \\
\hline i) ARR & 1,14 & 1,05 & - & Recommended \\
\hline j) Sensitivity Analysis & 1,92 & 2,05 & + & Recommended \\
\hline k) VAR & 0,34 & $0,60^{*}$ & + & Recommended \\
\hline l) Real Options & 0,19 & 0,26 & + & \\
\hline
\end{tabular}

*** denotes a significant change at the $p<0,01$ level.

** denotes a significant change at the $p<0,05$ level.

$*$ denotes a significant change at the $p<0,1$ level.

\subsubsection{A Cross-country Comparison of Companies' Use of Capital Budgeting Methods}

Total use of capital budgeting methods (see Table 6) was higher in the U.S. in 1999 (413\%) and in continental Europe in 2003 (388\% in U.K., 360\% in Netherlands, 321\% in Germany and 308\% in France) than in Sweden in 2005 (297\%) and in 2008 (278\%). The biggest single difference between Swedish and U.S./continental European companies was in the use of real options, $2 \%$ in Sweden versus 27\%-53\% in the U.S./continental Europe. The low total use in Sweden is a bit surprising since the present study, contrary to the other two, concerns only listed companies, which could drive the results toward a more extensive use of capital budgeting methods. Listed companies are presumably more sophisticated and gather more decision-relevant information before an investment is made. Thus; if non-listed Swedish companies had also been included in the present study, the total use might have been even lower.

Graham and Harvey (2001) and Brounen et al. (2004) showed that discounting-based appraisal methods, in general, were used more extensively by large companies. These results were confirmed by the present study though, as noted, the differences between large and small Swedish-listed companies seemed to be smaller in 2008 than in 2005 .

Finally, contrary to U.S. and continental European companies, large Swedish companies used the unsophisticated payback method more frequently than did small Swedish companies.

\section{COMPANIES' USE OF DISCOUNT RATES WHEN EVALUATING FOREIGN INVESTMENTS}

\subsection{The Dependent Variables}

Finance textbooks recommend that each investment project should have a specific cost of capital. If a project increases the systematic risk in a company, then it should be discounted by a higher cost of capital. The key is to identify the risk factors in a project and then to include them in the discount rate (Brealey and Myers, 2003; Ross et. al, 2005; Lumby and Jones, 2003; Smart et al., 2007). The same rule of course applies to foreign investments. 
Following is a brief description of theoretical merits and drawbacks of the discount rates included in the survey. The discount rates are presented in order of preference:

1. A discount rate for the entire company should not be used when the profitability of foreign investments is calculated since it would not include country-specific components, such as currency risk and political risk, nor the industry-specific risk.

2. A discount rate for the foreign market (country-specific discount rate)

3. A divisional discount rate (if the project's line of business matches a domestic division) is, from a theoretical perspective, more preferable since they (at least) capture some of the specific risk components.

4. A risk-matched discount rate for the particular project (considering both country and industry)

5. A different discount rate for each cash flow component that has a different risk characteristic is even more theoretically sound since multiple risk components are considered.

Discount rate 1 is not recommended, while discount rates 2-5 are recommended since they consider one or several specific risk factors. The drawback of discount rates 2-5 is that they are harder to establish.

\subsection{Results}

4.2.1 The Relation between Company Characteristics and Use of Discount Rates when Evaluating Foreign Investments

In $2005,41 \%$ of all respondent companies used a single company-wide discount rate when evaluating foreign investment, falling to $30 \%$ in 2008 (see Tables 8 and 9), while use of a country-specific discount rate remained constant at $31 \%$ in both years. It thus seems as if the more sophisticated country-specific discount rate has gained in relative popularity.

In both 2005 and 2008, larger companies generally employed sophisticated discount rates (which consider extra risk components) more frequently than did smaller ones. In 2005, non-manufacturing companies generally used sophisticated types of rates more often than did manufacturers, as they did in 2008 as well, though the results in 2008 were not significant.

Moreover, in both 2005 and 2008, dividend-paying companies employed a country specific discount rate significantly more frequent than did non-dividend paying companies. Surprisingly, companies with a higher amount of foreign income (which could indicate a higher level of foreign investments) did not seem to use more sophisticated methods than companies with a lower amount of foreign income when making investments abroad. 
Table 8: Swedish-listed Companies' Use of Discount Rates when Evaluating Foreign Investment in 2005

\begin{tabular}{|c|c|c|c|c|c|c|c|c|c|c|}
\hline \multirow[b]{2}{*}{ Type of Discount Rate } & \multirow{2}{*}{$\begin{array}{c}\text { Use } \\
\%\end{array}$} & \multirow[b]{2}{*}{ Mean } & \multicolumn{2}{|c|}{ Size } & \multicolumn{2}{|c|}{$\mathbf{P} / \mathbf{E}$} & \multicolumn{2}{|c|}{ Leverage } & \multicolumn{2}{|c|}{ Pay Dividends } \\
\hline & & & Small & Large & Growth & $\begin{array}{c}\text { Non- } \\
\text { growth }\end{array}$ & Low & High & Yes & No \\
\hline $\begin{array}{l}\text { a) The discount rate for the entire } \\
\text { company }\end{array}$ & 40,9 & 1,81 & 1,93 & 1,42 & 2,08 & 1,66 & 1,82 & 1,79 & 1,76 & 1,87 \\
\hline $\begin{array}{l}\text { b) The discount rate for the } \\
\text { overseas market (country discount } \\
\text { rate) }\end{array}$ & 31,4 & 1,40 & 1,21 & $1,96 * *$ & 1,38 & 1,38 & 1,29 & 1,64 & 1,71 & $0,96 * *$ \\
\hline $\begin{array}{l}\text { c) A divisional discount rate (if the } \\
\text { project line of business matches a } \\
\text { domestic division) }\end{array}$ & 8,6 & 0,62 & 0,59 & 0,71 & 0,51 & 0,68 & 0,60 & 0,68 & 0,63 & 0,61 \\
\hline $\begin{array}{l}\text { d) A risk-matched discount rate for } \\
\text { this particular project (considering } \\
\text { both country and industry) }\end{array}$ & 16,2 & 0,88 & 0,68 & $1,54 * * *$ & 0,57 & $1,04 *$ & 0,90 & 0,82 & 1,05 & 0,65 \\
\hline \multirow[t]{2}{*}{$\begin{array}{l}\text { e) A different discount rate for each } \\
\text { cash flow component that has a } \\
\text { different risk characteristic }\end{array}$} & 6,67 & 0,48 & 0,46 & 0,54 & 0,30 & 0,57 & 0,42 & 0,64 & 0,44 & 0,52 \\
\hline & & & \multicolumn{2}{|c|}{ Industry } & \multicolumn{2}{|c|}{$\begin{array}{l}\text { Management } \\
\text { Own }\end{array}$} & \multicolumn{2}{|c|}{ CEO Age } & \multicolumn{2}{|c|}{ CEO Tenure } \\
\hline Type of Discount Rate & $\begin{array}{c}\text { Use } \\
\%\end{array}$ & Mean & Manuf. & Others & Low & High & Old & Young & Long & Short \\
\hline $\begin{array}{l}\text { a) The discount rate for the entire } \\
\text { company }\end{array}$ & 40,9 & 1,81 & 1,78 & 1,83 & 1,89 & 1,38 & 1,65 & 1,98 & 1,86 & 1,82 \\
\hline $\begin{array}{l}\text { b) The discount rate for the } \\
\text { overseas market (country discount } \\
\text { rate) }\end{array}$ & 31,4 & 1,40 & 1,43 & 1,35 & 1,37 & 1,38 & 1,36 & 1,40 & 1,10 & 1,47 \\
\hline $\begin{array}{l}\text { c) A divisional discount rate (if the } \\
\text { project line of business matches a } \\
\text { domestic division) }\end{array}$ & 8,6 & 0,62 & 0,35 & $0,78^{*}$ & 0,62 & 0,94 & 0,56 & 0,68 & 0,52 & 0,65 \\
\hline $\begin{array}{l}\text { d) A risk-matched discount rate for } \\
\text { this particular project (considering } \\
\text { both country and industry) }\end{array}$ & 16,2 & 0,88 & 0,75 & 0,95 & 0,92 & 1,06 & 1,04 & 0,70 & 0,76 & 0,92 \\
\hline \multirow[t]{2}{*}{$\begin{array}{l}\text { e) A different discount rate for each } \\
\text { cash flow component that has a } \\
\text { different risk characteristic }\end{array}$} & 6,67 & 0,48 & 0,15 & $0,68 *$ & 0,47 & 0,69 & 0,58 & 0,36 & 0,52 & 0,47 \\
\hline & & & CEO & Master & $\begin{array}{r}\text { Targ } \\
\mathbf{R} \\
\end{array}$ & $\begin{array}{l}\text { Debt } \\
\text { io }\end{array}$ & Fore & n Sales & & \\
\hline Type of Discount Rate & $\begin{array}{c}\text { Use } \\
\%\end{array}$ & Mean & Yes & No & No & Yes & Yes & No & & \\
\hline $\begin{array}{l}\text { a) The discount rate for the entire } \\
\text { company }\end{array}$ & 40,9 & 1,81 & 1,47 & 1,96 & 1,37 & 2,03 & 1,89 & 1,52 & & \\
\hline $\begin{array}{l}\text { b) The discount rate for the } \\
\text { overseas market (country discount } \\
\text { rate) }\end{array}$ & 31,4 & 1,40 & 1,56 & 1,45 & 1,35 & 1,43 & 1,42 & 1,19 & & \\
\hline $\begin{array}{l}\text { c) A divisional discount rate (if the } \\
\text { project line of business matches a } \\
\text { domestic division) }\end{array}$ & 8,6 & 0,62 & 0,92 & 0,58 & 0,71 & 0,38 & 0,51 & $1,00^{*}$ & & \\
\hline $\begin{array}{l}\text { d) A risk-matched discount rate for } \\
\text { this particular project (considering } \\
\text { both country and industry) }\end{array}$ & 16,2 & 0,88 & 1,17 & 0,74 & 0,92 & 0,84 & 0,88 & 0,86 & & \\
\hline $\begin{array}{l}\text { e) A different discount rate for each } \\
\text { cash flow component that has a } \\
\text { different risk characteristic }\end{array}$ & 6,67 & 0,48 & 0,47 & 0,53 & 0,57 & 0,32 & 0,51 & 0,33 & & \\
\hline
\end{tabular}


Table 9: Swedish-listed Companies' Use of Discount Rates when Evaluating Foreign Investment in 2008

\begin{tabular}{|c|c|c|c|c|c|c|c|c|c|c|}
\hline \multirow[b]{2}{*}{ Type of Discount Rate } & \multirow[b]{2}{*}{$\begin{array}{l}\text { Use } \\
\%\end{array}$} & \multirow[b]{2}{*}{ Mean } & \multicolumn{2}{|c|}{ Size } & \multicolumn{2}{|c|}{$\mathbf{P} / \mathbf{E}$} & \multicolumn{2}{|c|}{ Leverage } & \multicolumn{2}{|c|}{ Pay Dividends } \\
\hline & & & Small & Large & Growth & $\begin{array}{c}\text { Non- } \\
\text { growth }\end{array}$ & Low & High & Yes & No \\
\hline $\begin{array}{l}\text { a) The discount rate for the entire } \\
\text { company }\end{array}$ & 29,9 & 1,32 & 1,35 & 1,24 & 1,67 & 1,14 & 1,31 & 1,36 & 1,48 & 1,06 \\
\hline $\begin{array}{l}\text { b) The discount rate for the } \\
\text { overseas market (country discount } \\
\text { rate) }\end{array}$ & 31,0 & 1,53 & 1,30 & $2,24 * *$ & 1,27 & 1,67 & 1,37 & 1,86 & 1,80 & $1,09 * *$ \\
\hline $\begin{array}{l}\text { c) A divisional discount rate (if the } \\
\text { project line of business matches a } \\
\text { domestic division) }\end{array}$ & 11,5 & 0,54 & 0,61 & 0,33 & 0,53 & 0,54 & 0,51 & 0,61 & 0,48 & 0,64 \\
\hline $\begin{array}{l}\text { d) A risk-matched discount rate for } \\
\text { this particular project (considering } \\
\text { both country and industry) }\end{array}$ & 26,4 & 1,03 & 0,86 & $1,57^{*}$ & 0,90 & 1,11 & 1,03 & 1,04 & 1,04 & 1,03 \\
\hline \multirow[t]{2}{*}{$\begin{array}{l}\text { e) A different discount rate for each } \\
\text { cash flow component that has a } \\
\text { different risk characteristic }\end{array}$} & 9,2 & 0,48 & 0,42 & 0,67 & 0,63 & 0,40 & 0,44 & 0,57 & 0,37 & 0,67 \\
\hline & & & \multicolumn{2}{|c|}{ Industry } & \multicolumn{2}{|c|}{$\begin{array}{l}\text { Management } \\
\text { Own }\end{array}$} & \multicolumn{2}{|c|}{ CEO Age } & \multicolumn{2}{|c|}{ CEO Tenure } \\
\hline Type of Discount Rate & $\begin{array}{c}\text { Use } \\
\%\end{array}$ & Mean & Manuf. & Others & Low & High & Old & Young & Long & Short \\
\hline $\begin{array}{l}\text { a) The discount rate for the entire } \\
\text { company }\end{array}$ & 29,9 & 1,32 & 1,32 & 1,32 & 1,39 & 0,92 & 1,05 & 1,54 & 0,80 & 1,39 \\
\hline $\begin{array}{l}\text { b) The discount rate for the } \\
\text { overseas market (country discount } \\
\text { rate) }\end{array}$ & 31,0 & 1,53 & 1,46 & 1,58 & 1,72 & $0,46^{* * *}$ & 1,49 & 1,56 & 1,20 & 1,57 \\
\hline $\begin{array}{l}\text { c) A divisional discount rate (if the } \\
\text { project line of business matches a } \\
\text { domestic division) }\end{array}$ & 11,5 & 0,54 & 0,46 & 0,60 & 0,54 & 0,54 & 0,46 & 0,60 & 0,50 & 0,55 \\
\hline $\begin{array}{l}\text { d) A risk-matched discount rate for } \\
\text { this particular project (considering } \\
\text { both country and industry) }\end{array}$ & 26,4 & 1,03 & 0,84 & 1,18 & 1,07 & 0,85 & 1,03 & 1,04 & 1,10 & 1,03 \\
\hline \multirow[t]{2}{*}{$\begin{array}{l}\text { e) A different discount rate for each } \\
\text { cash flow component that has a } \\
\text { different risk characteristic }\end{array}$} & 9,2 & 0,48 & 0,46 & 0,50 & 0,46 & 0,62 & 0,62 & 0,38 & 0,20 & 0,52 \\
\hline & & & \multicolumn{2}{|c|}{ CEO Master } & \multicolumn{2}{|c|}{$\begin{array}{l}\text { Target Debt } \\
\text { Ratio }\end{array}$} & \multicolumn{2}{|c|}{ Foreign Sales } & & \\
\hline Type of Discount Rate & $\begin{array}{c}\text { Use } \\
\%\end{array}$ & Mean & Yes & No & No & Yes & Yes & No & & \\
\hline $\begin{array}{l}\text { a) The discount rate for the entire } \\
\text { company }\end{array}$ & 29,9 & 1,32 & 1,32 & 1,33 & 1,17 & 1,58 & 1,52 & $0,73 * *$ & & \\
\hline $\begin{array}{l}\text { b) The discount rate for the } \\
\text { overseas market (country discount } \\
\text { rate) }\end{array}$ & 31,0 & 1,53 & 1,68 & 1,39 & 1,57 & 1,45 & 1,51 & 1,59 & & \\
\hline $\begin{array}{l}\text { c) A divisional discount rate (if the } \\
\text { project line of business matches a } \\
\text { domestic division) }\end{array}$ & 11,5 & 0,54 & 0,59 & 0,50 & 0,63 & 0,39 & 0,51 & 0,64 & & \\
\hline $\begin{array}{l}\text { d) A risk-matched discount rate for } \\
\text { this particular project (considering } \\
\text { both country and industry) }\end{array}$ & 26,4 & 1,03 & 1,24 & 0,85 & 1,02 & 1,06 & 0,97 & 1,23 & & \\
\hline $\begin{array}{l}\text { e) A different discount rate for each } \\
\text { cash flow component that has a } \\
\text { different risk characteristic }\end{array}$ & 9,2 & 0,48 & 0,56 & 0,41 & 0,39 & 0,64 & 0,46 & 0,55 & & \\
\hline
\end{tabular}

\subsubsection{Changes Over Time in Swedish Companies' Use of Discount Rates when Evaluating Foreign Investments}

Although changes between 2005 and 2008 in Swedish companies' use of discount rates, when evaluating foreign investments, were small, they could indicate increased sophistication. Use of recommended methods had (C) 2012 The Clute Institute http://www.cluteinstitute.com/ 
generally increased or stayed the same in 2008, while the only significant result was less use of the notrecommended company discount rate (see Table 10). That rate had been most used in 2005 while in 2008, the more theoretically sound country discount rate was most used.

Table 10: Changes in Use of Discount Rates between 2005 and 2008 by Swedish-listed Companies in Evaluating Foreign Investments

\begin{tabular}{|l|c|c|c|c|}
\hline \multicolumn{1}{|c|}{ Method } & Mean Values 2005 & $\begin{array}{c}\text { Mean Values } \\
\mathbf{2 0 0 8}\end{array}$ & $\begin{array}{c}\text { Change between 2005 } \\
\text { and 2008: + Denotes } \\
\text { Increase - Decrease }\end{array}$ & $\begin{array}{c}\text { Recommended or Not } \\
\text { by Textbooks }\end{array}$ \\
\hline $\begin{array}{l}\text { a) The discount rate for the entire } \\
\text { company }\end{array}$ & 1,81 & $1,32^{* *}$ & - & Not recommended \\
\hline $\begin{array}{l}\text { b) The discount rate for the } \\
\text { overseas market (country discount } \\
\text { rate) }\end{array}$ & 1,38 & 1,53 & + & Recommended \\
\hline $\begin{array}{l}\text { c) A divisional discount rate (if the } \\
\text { project line of business matches a } \\
\text { domestic division) }\end{array}$ & 0,62 & 0,54 & Recommended \\
\hline $\begin{array}{l}\text { d) A risk-matched discount rate for } \\
\text { this particular project (considering } \\
\text { both country and industry) }\end{array}$ & 0,88 & 1,03 & + & Recommended \\
\hline $\begin{array}{l}\text { e) A different discount rate for } \\
\text { each component cash flow that } \\
\text { has a different risk characteristic }\end{array}$ & & & & Recommended \\
$* * *$ denotes a significant change at the $p<0,01$ level. \\
$* *$ denotes a significant change at the $p<0,05$ level. \\
$*$ denotes a significant change at the $p<0,1$ level.
\end{tabular}

\subsubsection{A Cross-country Comparison of Companies' Use of Discount Rates when Evaluating Foreign Investments}

Swedish-listed companies used country-specific discount rate, company discount rate, and discount rate considering both country and industry, most frequently (see Table 11), as did U.S., U.K. and German companies (Graham and Harvey, 2001; Brounen et al., 2004). The unsophisticated company discount rate was the most popular one in the U.S., continental Europe (with France as the only exception), and Sweden in 2005. In 2008, however, as noted, the relatively more sophisticated country-specific rate was the most common discount rate in Sweden.

In total, Swedish companies used discount rates, 104\% (2005) and 107\% (2008), less frequently than did U.S. (171\%), Dutch (126\%) and U.K. (113\%) companies, but more frequently than German (101\%) and French (91\%) companies.

Table 11: The Use of Discount Rates when Making Foreign Investments ${ }^{21}$

\begin{tabular}{|c|c|c|c|c|c|c|c|}
\hline \multirow[b]{5}{*}{ Type of Discount Rate } & \multicolumn{7}{|c|}{ Use in \% } \\
\hline & \multirow{3}{*}{\multicolumn{2}{|c|}{$\begin{array}{c}\text { Sweden } \\
\text { The Present } \\
\text { Study }\end{array}$}} & \multirow{4}{*}{$\begin{array}{c}\text { U.S. } \\
\text { Graham \& } \\
\text { Harvey } \\
(2001)\end{array}$} & \multirow{2}{*}{\multicolumn{4}{|c|}{$\begin{array}{l}\text { Continental Europe } \\
\text { Brounen et al. (2004) }\end{array}$}} \\
\hline & & & & & & & \\
\hline & & & & \multirow[t]{2}{*}{ U.K. } & \multirow[t]{2}{*}{$\begin{array}{l}\text { Nether- } \\
\text { lands }\end{array}$} & \multirow[t]{2}{*}{ Germany } & \multirow{2}{*}{ France } \\
\hline & 2005 & 2008 & & & & & \\
\hline a) The discount rate for the entire company & $41 \%$ & $30 \%$ & $59 \%$ & $41 \%$ & $65 \%$ & $42 \%$ & $24 \%$ \\
\hline $\begin{array}{l}\text { b) The discount rate for the overseas market (country } \\
\text { discount rate) }\end{array}$ & $31 \%$ & $31 \%$ & $35 \%$ & $20 \%$ & $15 \%$ & $15 \%$ & $27 \%$ \\
\hline $\begin{array}{l}\text { c) A divisional discount rate (if the project line of } \\
\text { business matches a domestic division) }\end{array}$ & $9 \%$ & $11 \%$ & $16 \%$ & $17 \%$ & $17 \%$ & $12 \%$ & $16 \%$ \\
\hline $\begin{array}{l}\text { d) A risk-matched discount rate for this particular } \\
\text { project (considering both country and industry) }\end{array}$ & $16 \%$ & $26 \%$ & $51 \%$ & $24 \%$ & $27 \%$ & $25 \%$ & $13 \%$ \\
\hline $\begin{array}{l}\text { e) A different discount rate for each component cash } \\
\text { flow that has a different risk characteristic }\end{array}$ & $7 \%$ & $9 \%$ & $10 \%$ & $11 \%$ & $2 \%$ & $7 \%$ & $11 \%$ \\
\hline Total Use & $104 \%$ & $107 \%$ & $171 \%$ & $113 \%$ & $126 \%$ & $101 \%$ & $91 \%$ \\
\hline
\end{tabular}

${ }^{21}$ Respondents who answered that they "always" (represented by the highest score - 4) or "almost always" (represented by 3 ) used a method are defined as "users" of that method. 


\section{COMPANIES' USE OF COST-OF-EQUITY ESTIMATION METHODS}

\subsection{The Dependent Variables}

As noted, finance textbooks recommend that each investment project should have a specific cost of capital. The cost of capital, or WACC, consists of two main variables - cost of equity and cost of debt. Here it will be investigated how the cost of equity is estimated in Swedish-listed companies, but first is a short review of the six cost-of-equity estimation techniques included in the survey.

The two methods that can be regarded as sophisticated are those recommended - CAPM, although it has been challenged (Fama and French, 2004), and CAPM - but including some extra "risk factors" (CAPM+) since both consider systematic risk (Brealey and Myers, 2003; Ross et al., 2005; Lumby and Jones, 2003; Smart et al., 2007).

The methods that can be classified as unsophisticated and not recommended are: 1) average historical returns on common stock since it does not consider how the historical returns correlate with the market return, 2) regulatory decisions since they are not necessarily based on economic events or conditions, 3) an indirect method where the cost of equity is backed out of the dividend discount model since there are two unknown variables in that model (i.e., growth and cost of equity), which means that the only way to establish the cost of equity is to assume/guess the future growth variable, and 4) the investors' explicitly stated required return since it is far from sure that the required returns are based on the systematic risk.

\subsection{Results}

\subsubsection{The Relation between Company Characteristics and Use of Cost of Equity Estimation Methods}

The most employed method in 2005 (see Table 12) was investors' stated required return, 41\%, which fell to $30 \%$ in 2008. In 2008, the most used method (see Table 13) was CAPM, 31\%, falling from 33\% in 2005.

Large Swedish-listed companies used CAPM and CAPM+ more often than did small companies in 2005, which supports results of Graham and Harvey (2001), Brounen et al. (2004) and Silvola (2006), but usage converged and the difference was not significant in 2008. Management-owned companies used average historical returns on common stock significantly more than others did in both 2005 and 2008. When top managers have a larger stake in the company, they, as opposed to mutual funds, for example, are less diversified and could be more inclined to consider the company-specific risk and not just the systematic risk. Management-owned companies also used $\mathrm{CAPM}$ and CAPM+ (which both assume diversified ownership) less, though the differences were not significant. A negative relationship between managerial ownership and CAPM/CAPM+ should therefore, at best, be considered indicative. 
Table 12: How the Cost of Equity was Estimated by Swedish-listed Companies in 2005

\begin{tabular}{|c|c|c|c|c|c|c|c|c|c|c|}
\hline \multirow[b]{2}{*}{$\begin{array}{c}\text { Cost of Equity Estimation } \\
\text { Method }\end{array}$} & \multirow[b]{2}{*}{$\begin{array}{l}\text { Use } \\
\%\end{array}$} & \multirow[b]{2}{*}{ Mean } & \multicolumn{2}{|c|}{ Size } & \multicolumn{2}{|c|}{$\mathbf{P} / \mathbf{E}$} & \multicolumn{2}{|c|}{ Leverage } & \multicolumn{2}{|c|}{ Pay Dividends } \\
\hline & & & Small & Large & Growth & $\begin{array}{l}\text { Non- } \\
\text { growth }\end{array}$ & Low & High & Yes & No \\
\hline $\begin{array}{l}\text { a) With average historical returns } \\
\text { on common stock }\end{array}$ & 9,3 & 0,56 & 0,63 & 0,45 & 0,29 & 0,68 & 0,42 & 0,83 & 0,58 & 0,50 \\
\hline $\begin{array}{l}\text { b) Using the Capital Asset Pricing } \\
\text { Model (CAPM, the "beta" } \\
\text { approach) }\end{array}$ & 33,3 & 1,46 & 1,09 & $2,00^{*}$ & 1,29 & 1,54 & 1,67 & 1,06 & 1,68 & 0,86 \\
\hline $\begin{array}{l}\text { c) Using the CAPM but including } \\
\text { some extra "risk factors" }\end{array}$ & 27,8 & 1,04 & 0,63 & $1,64 * *$ & 1,12 & 1,00 & 0,86 & 1,39 & 1,10 & 0,86 \\
\hline $\begin{array}{l}\text { d) Whatever our investors tell us } \\
\text { they require }\end{array}$ & 40,7 & 1,72 & 2,00 & 1,32 & 1,76 & 1,70 & 1,72 & 1,72 & 1,65 & 1,93 \\
\hline e) By regulatory decisions & 5,60 & 0,41 & 0,38 & 0,45 & 0,59 & 0,32 & 0,31 & 0,61 & 0,43 & 0,36 \\
\hline $\begin{array}{l}\text { f) Back out from discounted } \\
\text { dividend/earnings model, e.g. } \\
\text { Price=Div./ (cost of cap. - } \\
\text { growth) }\end{array}$ & 5,60 & 0,46 & 0,38 & 0,59 & 0,41 & 0,49 & 0,36 & 0,67 & 0,45 & 0,50 \\
\hline & & & \multicolumn{2}{|c|}{ Industry } & \multicolumn{2}{|c|}{ Management Own } & \multicolumn{2}{|c|}{ CEO Age } & \multicolumn{2}{|c|}{ CEO Tenure } \\
\hline $\begin{array}{c}\begin{array}{c}\text { Cost of Equity Estimation } \\
\text { Method }\end{array} \\
\end{array}$ & $\begin{array}{c}\text { Use } \\
\%\end{array}$ & Mean & Manuf. & Others & Low & High & Old & Young & Long & Short \\
\hline $\begin{array}{l}\text { a) With average historical returns } \\
\text { on common stock }\end{array}$ & 9,3 & 0,56 & 0,32 & 0,72 & 0,49 & $1,75^{* *}$ & 0,57 & 0,54 & 0,82 & 0,49 \\
\hline $\begin{array}{l}\text { b) Using the Capital Asset Pricing } \\
\text { Model (CAPM, the "beta" } \\
\text { approach) }\end{array}$ & 33,3 & 1,46 & 1,59 & 1,38 & 1,55 & 0,50 & 1,57 & 1,35 & 1,18 & 1,53 \\
\hline $\begin{array}{l}\text { c) Using the CAPM but including } \\
\text { some extra "risk factors" }\end{array}$ & 27,8 & 1,04 & 0,91 & 1,13 & 1,06 & 0,50 & 1,11 & 0,96 & 0,73 & 1,12 \\
\hline $\begin{array}{l}\text { d) Whatever our investors tell us } \\
\text { they require }\end{array}$ & 40,7 & 1,72 & 1,32 & 2,00 & 1,87 & 1,25 & 1,82 & 1,62 & 1,09 & 1,88 \\
\hline e) By regulatory decisions & 5,60 & 0,41 & 0,32 & 0,47 & 0,36 & 0,25 & 0,43 & 0,38 & 0,55 & 0,37 \\
\hline $\begin{array}{l}\text { f) Back out from discounted } \\
\text { dividend/earnings model, e.g. } \\
\begin{array}{l}\text { Price=Div./ (cost of cap. - } \\
\text { growth) }\end{array}\end{array}$ & 5,60 & 0,46 & 0,18 & $0,66^{*}$ & 0,45 & 0,50 & 0,54 & 0,38 & 0,55 & 0,44 \\
\hline & & & \multicolumn{2}{|c|}{ CEO Master } & \multicolumn{2}{|c|}{ Target Debt Ratio } & \multicolumn{2}{|c|}{ Foreign Sales } & & \\
\hline $\begin{array}{c}\text { Cost of Equity Estimation } \\
\text { Method }\end{array}$ & $\begin{array}{c}\text { Use } \\
\%\end{array}$ & Mean & Yes & No & No & Yes & Yes & No & & \\
\hline $\begin{array}{l}\text { a) With average historical returns } \\
\text { on common stock }\end{array}$ & 9,3 & 0,56 & 0,42 & 0,63 & 0,50 & 0,52 & 0,45 & 1,00 & & \\
\hline $\begin{array}{l}\text { b) Using the Capital Asset Pricing } \\
\text { Model (CAPM, the "beta" } \\
\text { approach) }\end{array}$ & 33,3 & 1,46 & 1,47 & 1,74 & 1,29 & 1,72 & 1,59 & 0,90 & & \\
\hline $\begin{array}{l}\text { c) Using the CAPM but including } \\
\text { some extra "risk factors" }\end{array}$ & 27,8 & 1,04 & 1,37 & 0,96 & 0,75 & 1,40 & 0,95 & 1,40 & & \\
\hline $\begin{array}{l}\text { d) Whatever our investors tell us } \\
\text { they require }\end{array}$ & 40,7 & 1,72 & 1,74 & 1,70 & 1,64 & 1,88 & 1,55 & $2,50 *$ & & \\
\hline e) By regulatory decisions & 5,60 & 0,41 & 0,47 & 0,44 & 0,50 & 0,32 & 0,34 & 0,70 & & \\
\hline $\begin{array}{l}\text { f) Back out from discounted } \\
\text { dividend/earnings model, e.g. } \\
\text { Price=Div./ (cost of cap. - } \\
\text { growth) }\end{array}$ & 5,60 & 0,46 & 0,42 & 0,56 & 0,39 & 0,56 & 0,41 & 0,70 & & \\
\hline
\end{tabular}


Table 13: How the Cost of Equity was Estimated by Swedish-listed Companies in 2008

\begin{tabular}{|c|c|c|c|c|c|c|c|c|c|c|}
\hline \multirow[b]{2}{*}{$\begin{array}{c}\text { Cost of Equity Estimation } \\
\text { Method }\end{array}$} & \multirow[b]{2}{*}{$\begin{array}{c}\text { Use } \\
\%\end{array}$} & \multirow[b]{2}{*}{ Mean } & \multicolumn{2}{|c|}{ Size } & \multicolumn{2}{|c|}{$\mathbf{P} / \mathbf{E}$} & \multicolumn{2}{|c|}{ Leverage } & \multicolumn{2}{|c|}{$\begin{array}{c}\text { Pay } \\
\text { Dividends }\end{array}$} \\
\hline & & & Small & Large & Growth & $\begin{array}{l}\text { Non- } \\
\text { growth }\end{array}$ & Low & High & Yes & No \\
\hline $\begin{array}{l}\text { a) With average historical returns } \\
\text { on common stock }\end{array}$ & 14,8 & 0,69 & 0,70 & 0,65 & 1,00 & 0,55 & 0,79 & 0,52 & 0,60 & 1,00 \\
\hline $\begin{array}{l}\text { b) Using the Capital Asset Pricing } \\
\text { Model (CAPM, the "beta" } \\
\text { approach) }\end{array}$ & 31,4 & 1,56 & 1,54 & 1,59 & 1,06 & 1,76 & 1,48 & 1,67 & 1,45 & 1,92 \\
\hline $\begin{array}{l}\text { c) Using the CAPM but including } \\
\text { some extra "risk factors" }\end{array}$ & 24,1 & 1,06 & 1,05 & 1,06 & 1,50 & 0,87 & 1,00 & 1,14 & 1,02 & 1,17 \\
\hline $\begin{array}{l}\text { d) Whatever our investors tell us } \\
\text { they require }\end{array}$ & 29,6 & 1,31 & 1,59 & $0,71 * *$ & 1,19 & 1,37 & 1,00 & $1,81 * *$ & 1,43 & 0,92 \\
\hline e) By regulatory decisions & 9,30 & 0,48 & 0,54 & 0,35 & 0,25 & 0,58 & 0,24 & $0,86 * *$ & 0,60 & 0,08 \\
\hline $\begin{array}{l}\text { f) Back out from discounted } \\
\text { dividend/earnings model, e.g. } \\
\text { Price=Div./ (cost of cap. }- \text { growth) }\end{array}$ & 3,70 & 0,31 & 0,30 & 0,35 & 0,56 & 0,21 & 0,24 & 0,43 & 0,33 & 0,25 \\
\hline & & & Indi & try & $\begin{array}{r}\text { Manas } \\
\text { O }\end{array}$ & nent & & Age & CEO & 'enure \\
\hline $\begin{array}{c}\text { Cost of Equity Estimation } \\
\text { Method }\end{array}$ & $\begin{array}{c}\text { Use } \\
\%\end{array}$ & Mean & Manuf. & Others & Low & High & Old & Young & Long & Short \\
\hline $\begin{array}{l}\text { a) With average historical returns } \\
\text { on common stock }\end{array}$ & 14,8 & 0,69 & 0,73 & 0,66 & 0,58 & $1,50 *$ & 0,75 & 0,62 & 1,40 & 0,61 \\
\hline $\begin{array}{l}\text { b) Using the Capital Asset Pricing } \\
\text { Model (CAPM, the "beta" } \\
\text { approach) }\end{array}$ & 31,4 & 1,56 & 1,50 & 1,59 & 1,58 & 1,33 & 1,36 & 1,77 & 0,20 & $1,69 *$ \\
\hline $\begin{array}{l}\text { c) Using the CAPM but including } \\
\text { some extra "risk factors" }\end{array}$ & 24,1 & 1,06 & 1,09 & 1,03 & 1,13 & 0,50 & 1,00 & 1,12 & 0,00 & 1,16 \\
\hline $\begin{array}{l}\text { d) Whatever our investors tell us } \\
\text { they require }\end{array}$ & 29,6 & 1,31 & 0,95 & 1,56 & 1,33 & 1,17 & 0,61 & $2,08 * * *$ & 1,40 & 1,31 \\
\hline e) By regulatory decisions & 9,30 & 0,48 & 0,32 & 0,59 & 0,46 & 0,67 & 0,68 & 0,27 & 1,60 & 0,37 \\
\hline $\begin{array}{l}\text { f) Back out from discounted } \\
\text { dividend/earnings model, e.g. } \\
\text { Price=Div./ (cost of cap. }- \text { growth) }\end{array}$ & 3,70 & 0,31 & 0,18 & 0,41 & 0,35 & 0,00 & 0,14 & 0,50 & 0,20 & 0,33 \\
\hline & & & CEO I & Iaster & $\begin{array}{r}\text { Targe } \\
\mathbf{R a} \\
\end{array}$ & $\begin{array}{l}\text { Debt } \\
\text { io }\end{array}$ & Fore & n Sales & & \\
\hline $\begin{array}{c}\text { Cost of Equity Estimation } \\
\text { Method }\end{array}$ & $\begin{array}{c}\text { Use } \\
\%\end{array}$ & Mean & Yes & No & No & Yes & Yes & No & & \\
\hline $\begin{array}{l}\text { a) With average historical returns } \\
\text { on common stock }\end{array}$ & 14,8 & 0,69 & 0,87 & 0,43 & 0,70 & 0,67 & 0,56 & 1,08 & & \\
\hline $\begin{array}{l}\text { b) Using the Capital Asset Pricing } \\
\text { Model (CAPM, the "beta" } \\
\text { approach) }\end{array}$ & 31,4 & 1,56 & 1,42 & 1,74 & 1,93 & $1,08^{*}$ & 1,73 & 1,00 & & \\
\hline $\begin{array}{l}\text { c) Using the CAPM but including } \\
\text { some extra "risk factors" }\end{array}$ & 24,1 & 1,06 & 1,03 & 1,09 & 1,13 & 0,96 & 1,22 & 0,54 & & \\
\hline $\begin{array}{l}\text { d) Whatever our investors tell us } \\
\text { they require }\end{array}$ & 29,6 & 1,31 & 1,16 & 1,52 & 1,10 & 1,58 & 1,29 & 1,38 & & \\
\hline e) By regulatory decisions & 9,30 & 0,48 & 0,61 & 0,30 & 0,40 & 0,58 & 0,24 & $1,23 * * *$ & & \\
\hline $\begin{array}{l}\text { f) Back out from discounted } \\
\text { dividend/earnings model, e.g. } \\
\text { Price=Div./ (cost of cap. - } \text { growth) }\end{array}$ & 3,70 & 0,31 & 0,39 & 0,22 & 0,23 & 0,42 & 0,29 & 0,38 & & \\
\hline
\end{tabular}

\subsubsection{Changes Over Time in Swedish Companies' Use of Cost-of-equity Estimation Methods}

In $2005,51 \%$ of Swedish-listed companies reported using cost-of-equity estimation methods, which rose to $61 \%$ in 2008 (see Table 14). Use of CAPM and CAPM+ rose slightly, but so did the use of some not-recommended 
methods. None of the changes were significant. The increased popularity of CAPM supports longitudinal survey data from U.S. companies (Gitman and Vandenberg, 2000).

In 2005, investor requirements had the highest mean value $(1,72)$ and the highest percentage of companies reporting using it $(41 \%)$. In 2008, CAPM had the highest mean value $(1,56)$ and most companies using it $(31 \%)$. Even though CAPM has been questioned (Jagannathan and Meier, 2002), it should still be regarded as a more sophisticated method than to ask the investors what they require (Bruner et al., 1998).

Table 14: Changes in How the Cost of Equity was estimated by Swedish-listed Companies between 2005 and 2008

\begin{tabular}{|l|c|c|c|l|}
\hline \multicolumn{1}{|c|}{ Method } & $\begin{array}{c}\text { Mean } \\
\text { Values } \\
\mathbf{2 0 0 5}\end{array}$ & $\begin{array}{c}\text { Mean } \\
\text { Values } \\
\mathbf{2 0 0 8}\end{array}$ & $\begin{array}{c}\text { Change between 2005 } \\
\text { and 2008: + Denotes } \\
\text { Increase - Decrease }\end{array}$ & $\begin{array}{c}\text { Recommended or Not } \\
\text { by Textbooks }\end{array}$ \\
\hline $\begin{array}{l}\text { Do you estimate the cost of equity capital? (no = 0, yes } \\
\text { =1) }\end{array}$ & 0,51 & 0,61 & + & Recommended \\
\hline a) With average historical returns on common stock & 0,56 & 0,69 & + & Not recommended \\
\hline $\begin{array}{l}\text { b) Using the Capital Asset Pricing Model (CAPM, the } \\
\text { "beta" approach) }\end{array}$ & 1,46 & 1,56 & + & Recommended \\
\hline $\begin{array}{l}\text { c) Using the CAPM but including some extra "risk } \\
\text { factors" }\end{array}$ & 1,04 & 1,06 & + & Recommended \\
\hline d) Whatever our investors tell us they require & 1,72 & 1,31 & - & Not recommended \\
\hline e) By regulatory decisions & 0,41 & 0,48 & + & Not recommended \\
\hline $\begin{array}{l}\text { f) Back out from discounted dividend/earnings model, } \\
\text { e.g. Price=Div./ (cost of cap. - growth) }\end{array}$ & 0,46 & 0,31 & - & Not recommended \\
\hline
\end{tabular}

*** denotes a significant change at the $p<0,01$ level.

** denotes a significant change at the $p<0,05$ level.

$*$ denotes a significant change at the $p<0,1$ level.

\subsubsection{A Cross-country Comparison of Companies' Use of Cost-of-equity Estimation Methods}

Again, overall, Swedish-listed companies used estimation methods less (123\% in 2005 and $112 \%$ in 2008), especially compared to U.S companies (183\%), but also continental European ones (see Table 15). In particular, Swedish companies used the more sophisticated CAPM (33\% in 2005 and 31\% in 2008) and the unsophisticated "average historical returns on common stock" ( $9 \%$ in 2005 and 15\% in 2008) less than U.S. and continental European companies.

Table 15: The Use of Cost-of-equity Estimation Methods ${ }^{22}$

\begin{tabular}{|c|c|c|c|c|c|c|c|}
\hline \multirow[b]{5}{*}{ Type of Capital Budgeting Method } & \multicolumn{7}{|c|}{ Use in \% } \\
\hline & \multirow{3}{*}{\multicolumn{2}{|c|}{$\begin{array}{c}\text { Sweden } \\
\text { The Present } \\
\text { Study }\end{array}$}} & \multirow{4}{*}{$\begin{array}{c}\text { The U.S. } \\
\text { Graham \& } \\
\text { Harvey (1999) }\end{array}$} & \multirow{2}{*}{\multicolumn{4}{|c|}{$\begin{array}{c}\text { Continental Europe } \\
\text { Brounen et al. (2004) }\end{array}$}} \\
\hline & & & & & & & \\
\hline & & & & \multirow[b]{2}{*}{ U.K } & \multirow{2}{*}{$\begin{array}{l}\text { Nether- } \\
\text { lands }\end{array}$} & \multirow[b]{2}{*}{ Germany } & \multirow[b]{2}{*}{ France } \\
\hline & $(2005)$ & $(2008)$ & & & & & \\
\hline $\begin{array}{l}\text { a) With average historical returns on common } \\
\text { stock }\end{array}$ & $9 \%$ & $15 \%$ & $39 \%$ & $31 \%$ & $31 \%$ & $18 \%$ & $27 \%$ \\
\hline $\begin{array}{l}\text { b) Using the Capital Asset Pricing Model (CAPM, } \\
\text { the "beta" approach) }\end{array}$ & $33 \%$ & $31 \%$ & $73 \%$ & $47 \%$ & $56 \%$ & $34 \%$ & $45 \%$ \\
\hline $\begin{array}{l}\text { c) Using the CAPM but including some extra "risk } \\
\text { factors" }\end{array}$ & $28 \%$ & $24 \%$ & $34 \%$ & $27 \%$ & $15 \%$ & $16 \%$ & $30 \%$ \\
\hline d) Whatever our investors tell us they require & $41 \%$ & $29 \%$ & $14 \%$ & $19 \%$ & $45 \%$ & $39 \%$ & $34 \%$ \\
\hline e) By regulatory decisions & $6 \%$ & $9 \%$ & $7 \%$ & $16 \%$ & $4 \%$ & $0 \%$ & $1 \%$ \\
\hline $\begin{array}{l}\text { f) Back out from discounted dividend/earnings } \\
\text { model, e.g. Price=Div./ (cost of cap. }- \text { growth) }\end{array}$ & $6 \%$ & $4 \%$ & $16 \%$ & $10 \%$ & $11 \%$ & $10 \%$ & $1 \%$ \\
\hline Total Use & $123 \%$ & $112 \%$ & $183 \%$ & $150 \%$ & $162 \%$ & $117 \%$ & $138 \%$ \\
\hline
\end{tabular}

\footnotetext{
${ }^{22}$ Respondents who answered that they "always" (represented by the highest score - 4) or "almost always" (represented by 3 ) used a
} method are defined as "users" of that method. 


\section{DISCUSSION AND CONCLUSIONS}

Discounting-based capital budgeting methods, such as NPV, were more popular among large companies, but the difference fell from 2005 to 2008 as did differences between manufacturers and non-manufacturers, perhaps because of the natural selection. Managers who do not adopt efficient procedures will, in other words, be replaced either by the present board or, after acquisition, by a new board. Alternatively, companies that, because of unsophisticated capital budgeting methods, choose bad investments could go out of business. The suggested driving force is thus market pressures. Another possible explanation, not necessarily based on the belief that the observed behaviour is rational from an efficiency perspective, for why small and large companies and manufacturers and nonmanufacturers acted more similar in 2008 when it came to the employment of capital budgeting techniques, is that a process of coercive, mimetic and/or normative isomorphism has taken place (DiMaggio and Powell, 1983; Carpenter and Feroz, 2001). Since the results, however, also suggested that, for example, high and low leverage companies acted less similar in 2008 than in 2005, the idea of a process of (general) isomorphism is contradicted.

Companies with high managerial ownership used ARR less often. Since managerial ownership bridges the gap between ownership and control and leads to more symmetrical distribution of information, it is less likely that top managers (in those companies) are motivated, and if they are, get the opportunity to engage in opportunistic earnings management (Kim and Yi, 2006). If top mangers put less effort in managing earnings opportunistically, they could potentially also put less emphasis on estimating how investments affect the accounting numbers.

Not surprisingly, payback was more popular among companies with high financial leverage, presumable because contractual (fixed) periodic interest and principal payments put management under pressure to invest in projects giving quick positive net cash flows.

Swedish companies have increased the use of the recommended NPV since the 1960s. In most studies, the sample has consisted of the largest Swedish companies. An explanation for the increased use of NPV, consistent with legitimacy and stakeholder theory (Dowling and Pfeffer, 1975; Gray et al., 1996), could be that management in large companies, because of the greater gap between the agent (management) and the principal (shareholders/board), needs to legitimise its investments with methods considered theoretically sound. Because of its strong theoretical merits, NPV has been embraced by textbook authors and taught at business schools, making it one of the most socially acceptable methods. In addition, it has been suggested that the more shareholder-value oriented corporate governance regime since the 1990s (Brodin et al., 2000; Lazonick and O'Sullivan, 2000) has promoted the use of NPV when investment projects are to be justified.

An alternative explanation would (again) stress the importance of competition in product, manageriallabour, and capital markets. The argument goes that, because of competition, companies and managers that choose profitable (and rejects non-profitable) investments; i.e., choosing projects with positive NPV, will survive in the long run.

Somewhat surprisingly, between the 1960s and the first decade of the $21^{\text {st }}$ century, the utilisation of unsophisticated accounting-based capital budgeting methods increased in Swedish companies, perhaps because of management's fear of failing to meet earnings targets. Graham et al. (2005) documented that top management in U.S. companies was willing to sacrifice economic value (i.e., positive NPV-projects) in order to meet a short-term earnings target. It could thus be that top management in Swedish companies has become both more shareholder value-oriented (using NPV) and short-sighted (using accounting ratios).

In addition to the increased use of NPV and accounting ratios, employment of the not so theoretically appealing IRR and payback seems to be declining. Overall, the results indicate that the use of sophisticated methods has increased and the use of unsophisticated methods has decreased (with the exception of accounting ratios) in Swedish-listed companies, as has also been found in other countries.

The results were also compared to a U.S. (Graham and Harvey, 2001) and a continental European (Brounen et al., 2004) study. Total use of capital budgeting methods was generally higher in the U.S. and continental Europe than in Sweden despite the fact that the present study included only listed companies which probably use capital 
budgeting methods more than non-listed ones. This cross-country difference could be explained by cultural differences (Hofstede 1983, 1984) which management must adapt to. The studies also showed similarities. Larger companies, for example, seemed to utilise appraisal methods more often, in general, but size-related differences were also identified. One interesting size-related difference concerned the payback method. Contrary to U.S. and continental European companies, the unsophisticated payback method was employed more often by larger Swedish companies than by smaller ones.

Results regarding the use of discount rates when making investments abroad do not point out any particular variable driving most of the results even though, again, larger companies were more likely to consider specific risk factors, indicating a higher level of sophistication. Swedish listed companies in general employed the unsophisticated "company discount rate" significantly less frequent in 2008 than in 2005.

The most interesting finding regarding the utilisation of cost of equity estimation methods, was that the number of companies that estimated the cost of equity increased from $51 \%$ in 2005 to $61 \%$ in 2008 . Moreover, in 2008 CAPM was the most utilised method to establish the cost of equity, while in 2005 it was the investors' required return. This could indicate more awareness and advanced behaviour among Swedish listed companies, confirming longitudinal data from U.S. companies (Gitman and Vandenberg, 2000).

Significant differences in the use capital budgeting and cost of equity estimation methods (contingent on the independent variables), were much more common in especially the U.S. study (Graham and Harvey, 2001). It could be that the choice of independent variables better correspond to factors that affect the use of methods in the U.S. Another explanation could be that the U.S. sample (392 respondents), was larger than in the present study (105 respondents in 2005 and 88 respondents in 2008). When the sample is large, other things equal, small mean differences between two groups lead to statistically significant results.

\section{AUTHOR INFORMATION}

Fredrik Hartwig is a lecturer in accounting and finance at Gävle University and Swedish University of Agricultural Sciences in Uppsala. He received his Master of Business Administration degree from Uppsala University, where he currently attends a PhD-program in accounting and finance. He will defend his thesis 3 October 2012. E-mail: fredrik.hartwig@hig.se

\section{REFERENCES}

1. Andersson, B. (1994) Investeringar och energianvändning, Doctoral Thesis, Bas, Göteborg.

2. Albert-Roulhac, C. and Breen, P. (2005) "Corporate governance in Europe: Current status and future trends", Journal of Business Strategy, Vol. 26 (6), pp. 19-29.

3. Arnold, G.C. and Hatzopoulos, P.D. (2000) "The theory-practice gap in capital budgeting: Evidence from the United Kingdom", Journal of Business Finance and Accounting, Vol. 27 (5-6), pp. 603-626.

4. Bancel, F. and Mittoo, U.R. (2004) "Cross-country determinants of capital structure: A survey of European firms", Financial Management, Vol. 33 (4), pp. 103-132.

5. Bennouna, K., Meredith, G.G. and Marchant, T. (2010) "Improved capital budgeting decision making: Evidence from Canada", Management Decision, Vol. 48 (2), pp. 225-247.

6. Bloom, R. and Naciri, M.A. (1989) "Accounting standard setting and culture: A comparative analysis of the United States, Canada, England, West Germany, Australia, New Zealand, Sweden, Japan and Switzerland", International Journal of Accounting, Vol. 24 (1), pp. 70-97.

7. Boyle, G.W. and Guthrie, G.A. (1997) "Payback and the value of waiting to invest", University of Otago, Working paper.

8. Boyle, G. and Guthrie, G. (2006) "Payback without apology", Accounting and Finance, Vol. 46 (1), pp. 110.

9. Brealey, R.A. and Myers, S.C. (2003) Principles of Corporate Finance, $7^{\text {th }}$ International Edition, McGrawHill, New York.

10. Brodin, B., Lundkvist, L., Sjöstrand, S.E. and Östman, L. (2000) Koncernchefen och ägarna, Ekonomiska Forskningsinstitutet vid Handelshögskolan i Stockholm, Stockholm. 
11. Brounen, D., De Jong, A. and Koedijk, K. (2004) "Corporate finance in Europe: Confronting theory with practice”, Financial Management, Vol. 33 (4), pp. 71-101.

12. Bruner, R.F., Eades, K.M., Harris, R.S. and Higgins, R.C. (1998) "Best practices in estimating the cost of capital: Survey and synthesis", Financial Practice and Education, Vol. 8 (1), pp. 13-28.

13. Carpenter, V.L. and Feroz, E.H. (2001) "Institutional theory and accounting rule choice: An analysis of four US state governments' decisions to adopt generally accepted accounting principles", Accounting, Organizations and Society, Vol. 26 (7-8), pp. 565-596.

14. Chenhall, R.H. (2003) "Management control systems design within its organizational context: Findings from contingency-based research and directions for the future", Accounting Organizations and Society, Vol. 28 (2-3), pp. 127-168.

15. Danielson, M.G. and Scott, J.A. (2006) "The capital budgeting decisions of small businesses", Journal of Applied Finance, Vol. 16 (2), pp. 45-56.

16. DiMaggio, P.J. and Powell, W.W. (1983) "The iron cage revisited: Institutional isomorphism and collective rationality in organizational fields", American Sociological Review, Vol. 48 (2), pp. 147-160.

17. Dowling, J. and Pfeffer, J. (1975) “Organizational legitimacy: Social values and organizational behavior”, The Pacific Sociological Review, Vol. 18 (1), pp 122-136.

18. Eiteman, D.K., Stonehill, A.I. and Moffett, M. (2006) Multinational Business Finance, $11^{\text {th }}$ International Edition, Pearson Higher Education, Boston.

19. Fama, E.F. and French K.R. (2004) "The capital asset pricing model: Theory and evidence", Journal of Economic Perspectives, Vol. 18 (3), pp. 25-46.

20. Gitman, L.J. and Forrester J.R. (1977) "A survey of capital budgeting techniques used by major U.S. firms", Financial Management, Vol. 6 (3), pp. 66-71.

21. Gitman, L.J. and Mercurio, V. (1982) "Cost of capital techniques used by major U.S. firms: survey and analysis of Fortune's 1000”, Financial Management, Vol. 11 (4), pp. 21-29.

22. Gitman, L.J. and Maxwell, C.E. (1985) "Financial activities of major U.S. firms: Survey and analysis of fortune's 1000”, Financial Management, Vol. 14 (4) pp. 57-65.

23. Gitman, L.J. and Vandenberg, P.A. (2000) "Cost of capital techniques used by major US firms: 1997 vs. 1980”, Financial Practice and Education, Vol. 10 (2), pp. 53-68.

24. Graham, J.R. and Harvey, C.R. (2001) "The theory and practice of corporate finance: Evidence from the field”, Journal of Financial Economics, Vol. 60 (2-3), pp. 187-243.

25. Graham, J.R., Harvey, C.R. and Rajgopal S. (2005) "The economic implications of corporate financial reporting", Journal of Accounting and Economics, Vol. 40 (1-3), pp. 3-73.

26. Gray, R., Owen D. and Adams C. (1996) Accounting and Accountability: Changes and Challenges to Corporate and Environmental Reporting, Prentice-Hall, London.

27. Hofstede, G.H. (1983) "The cultural relativity of organizational practices and theories", Journal of International Business Studies, Vol. 14 (2), pp. 75-89.

28. Hofstede, G.H. (1984) Culture's Consequences: International differences in work-related values, London, Sage Publications.

29. Holmén and Pramborg (2009) "Capital budgeting and political risk: Empirical evidence”, Journal of International Financial Management and Accounting, Vol. 20 (2), pp. 105-134.

30. Jagannathan, R. and Meier, I. (2002) "Do we need CAPM for capital budgeting?", Financial Management, Vol. 31 (4), pp. 55-77.

31. Jensen, M.C. (1986) "Agency costs of free cash flow, corporate finance, and takeovers", The American Economic Review, Vol. 76 (2), pp. 323-329.

32. Jensen, M.C. and Meckling, W.H. (1976) "Theory of the firm: Managerial behaviour, agency costs and ownership structure”, Journal of Financial Economics, Vol. 3 (4), pp. 305-360.

33. Johansson D. and Østergren K. (2010) "The movement toward independent directors on boards: A comparative analysis of Sweden and the UK", Corporate Governance: An International Review, Vol. 18 (6), pp 527-539.

34. Jorion, P. (2006) Value at Risk: The new benchmark for managing financial risk, $3^{\text {rd }}$ Edition, McGraw-Hill, New York.

35. Kim, J.B. and Yi, C.H. (2006) "Ownership structure, business group affiliation, listing status, and earnings management: Evidence from Korea”, Contemporary Accounting Research, Vol. 23 (2) pp. 427-464. 
36. Klammer, T.P. (1972) "Empirical evidence of the adoption of sophisticated capital budgeting techniques", Journal of Business, Vol. 45 (3), pp. 387-397.

37. Klammer, T.P. and Walker, M.C. (1984) "The continuing increase in the use of sophisticated capital budgeting techniques", California Management Review, Vol. 27 (1), pp. 137-148.

38. Langfield-Smith, K. (1997) "Management control systems and strategy: A critical review", Accounting, Organizations and Society, Vol. 22 (2), pp. 207-232.

39. Lazonick, W. and O'Sullivan, M. (2000) "Maximizing shareholder value: A new ideology for corporate governance Economy and Society", Economy and Society, Vol. 29 (1), pp. 13-35.

40. Liljeblom, E. and Vaihekoski, M. (2004) "Investment evaluation methods and required rate of return in Finnish publicly listed companies", Finnish Journal of Business Economics, Vol. 53 (1), pp. 9-24.

41. Lumby, S. and Jones, C. (2003) Corporate Finance: Theory and Practice, $7^{\text {th }}$ Edition, Thomson Learning, London.

42. Macarthur, J.B. (1999) "The impact of cultural factors on the lobbying of the international accounting standards committee on E32, Comparability of Financial Statements: An extension of MacArthur to accounting member bodies", Journal of International Accounting, Auditing and Taxation, Vol. 8 (2), pp. 315-335.

43. Narayanan, M.P. (1985) "Observability and the payback criterion”, Journal of Business, Vol. 58 (3), pp. 309-323.

44. Pike, R. (1989) "Do sophisticated capital budgeting approaches improve investment decision-making effectiveness?", Engineering Economist, Vol. 34 (2), pp 149-161.

45. Pike, R. (1996) "A longitudinal survey on capital budgeting practices", Journal of Business Finance and Accounting, Vol. 23 (1), pp. 79-92.

46. Renck, O. (1966) Investeringsbedömning i några svenska företag, P.A. Nordstedt \& Söners Förlag, Stockholm.

47. Ross, S.A., Westerfield, R.W. and Jaffe, J. (2005) Corporate Finance, $7^{\text {th }}$ International Edition, New York, McGraw-Hill.

48. Ryan, P.A. and Ryan, G.P. (2002) "Capital budgeting practices of Fortune 1000: How have things changed?", Journal of Business and Management, Vol. 8 (4), pp. 355-364.

49. Sandahl, G. and Sjögren, S. (2003) "Capital budgeting methods among Sweden's largest groups of companies. The state of the art and a comparison with earlier studies", International Journal of Production Economics, Vol. 84 (1), pp. 51-69.

50. Segelod, E. (1995) Resource Allocation in Divisionalized Groups, Aldershot, Avebury.

51. Shapiro, A.C. (2002) Foundations of Multinational Financial Management, $4^{\text {th }}$ Edition, New York, John Wiley \& Sons, Inc.

52. Silvola, H. (2006) "Low-intensity R\&D and capital budgeting decisions in IT firms", Advances in Management Accounting, Vol. 15, pp. 21-49.

53. Smart, S.B., Megginson, W.L., and Gitman, L.J. (2007) Corporate Finance, $2^{\text {nd }}$ Edition, Mason, Thomson South-Western.

54. Tell, B. (1978) Investeringsbedömning i Praktiken, Studentlitteratur, Lund.

55. Trahan, E.A. and Gitman, L.J. (1995) "Bridging the theory-practice gap in corporate finance: A survey of chief financial officers", Quarterly Review of Economics and Finance, Vol. 35 (1), pp. 73-87.

56. Trong, G., Partington, G. and Peat, M. (2008) "Cost-of-capital estimation and capital-budgeting practice in Australia”, Australian Journal of Management, Vol. 33 (1), pp. 95-121.

57. Yard, S. (1987) Kalkyllogik och Kalkylkrav, Doctoral Thesis, Lund University Press, Lund. 